\title{
REGULATION AND LABOUR MARKET PERFORMANCE ${ }^{1}$
}

\author{
by \\ Tito Boeri (Università Bocconi-IGIER and CEPR) \\ Giuseppe Nicoletti (OECD) \\ Stefano Scarpetta $(O E C D)$
}

\begin{abstract}
The increasing literature on the interactions between liberalisation-integration of product markets and labour market reforms is often highly speculative and draws on a rather weak empirical basis. Cross-country indicators of regulatory frameworks are often lacking, making it difficult to identify the linkages with observed outcomes in the labour and product markets. Moreover, empirical studies have often focused exclusively on the impact of certain labour market regulations, largely ignoring the role of product market regulations and the interactions between regulatory interventions in the two markets. As a result, while there are convincing theoretical arguments pointing to a potentially positive effect of product market liberalisation on labour market performance, empirical investigations of this issue are lacking. This paper aims at providing some preliminary evidence on these issues. In particular, the cross-country patterns and changing profile of product and labour market regulations are identified. Evidence on the relationships between product and labour market regulations is discussed in the context of other policies and institutional factors affecting the labour market; and the clustering and convergence of institutions across countries are characterised. More importantly, the paper reports evidence of a potentially significant impact of product and labour market regulations on employment and its composition. The evidence presented draws heavily on a novel set of cross-country indicators of regulation in the product and labour markets assembled at the OECD. It should be stressed at the outset that these indicators are preliminary estimates and should be taken only as rough approximations of the regulatory stance across OECD countries. ${ }^{2}$
\end{abstract}

1. We thank Giampaolo Galli, Jaques Pelkman and Paolo Sestito as well as participants in the Workshop on "Regulatory Reform, Competitiveness and Market Functioning" for helpful comments on a previous draft of the paper. The views expressed in this paper are our own and should not be held to represent those of the OECD or its Member governments.

2. The indicators are used in this paper under the exclusive responsibility of the authors and do not engage the OECD or its Member countries. 
The plan of the paper is as follows. Section 1 reviews the theoretical and empirical evidence concerning the effects of regulations in the product and labour markets on the labour market. This section also sheds some light on the possible interactions between regulatory regimes in the two markets. Section 2 presents the quantitative indicators of the strictness of the labour market and product market regulations, while Section 3 discusses the cross-country co-variations between indicators of labour and product market regulations. This section also identifies some clusters of countries that share similar features in these two domains. Section 4 analyses the interactions between, on the one hand, PM and LM regulations, and, on the other hand, labour market performance with particular emphasis on the level and composition of employment. Finally, Section 5 evaluates the convergence of labour market institutions within and across the clusters identified in Section 3, which provides a preliminary test of the convergence and/or race-to-the-bottom hypothesis.

\section{Labour and product market regulations and their effects on the labour market}

Economic regulation can be broadly defined as the use of the coercive power of the government to restrict the decisions of economic agents. ${ }^{3}$ It may include restrictions on firm decisions over entry, exit, the use of inputs, the quantities and the types of output produced as well as prices. These restrictions are likely to affect significantly (in intended or unintended ways) the functioning of labour and product markets. Moreover, since market forces will continue to act even under the most stringent regulatory conditions, outcomes in the labour and product markets will generally be driven by the interplay of those forces with the existing regulatory framework. As a result, regulation can be expected to have important repercussions on overall allocative and productive efficiency. ${ }^{4}$

In the following, the focus is set on a subset of government-imposed restrictions that may affect the level and composition of employment. These include (i) labour market regulations disciplining hiring and firing decisions of firms; (ii) product market regulations restricting firm decisions over entry and output; and (iii) direct interventions of the state in resource allocation, especially through public ownership and control of business enterprises. Conceptually, these regulatory interventions may all have both direct and indirect effects on labour market equilibrium, either in isolation or interacting among them and with other public policies.

\subsection{The employment protection legislation: rationale and effects on the level and the dynamics of employment}

\subsubsection{The rationale and potential effects of employment protection legislation}

In all OECD countries, there are rules and regulations that govern the employment relationship between workers and firms. Those referring to hiring and firing practices are often referred to as "employment protection" legislation (EPL). These rules and regulations govern unfair dismissals, restrictions on lay-offs for economic reasons, compulsory severance payments, minimum notice periods and administrative authorisations.

3. For a discussion of the concept of economic regulation, see Viscusi et al. (1997).

4. For instance, the cost of US Federal regulations were estimated to range from 4 to 10 per cent of GDP (Office of Management and Budget, 1998), while the costs of regulation for the Dutch economy were estimated to range from 11 to 14 per cent of Net National Income (Bergeijk and Haffner, 1996). 
The EPL regulations may affect the equilibrium level of employment -- as well as its dynamics over the business cycle -- in different ways:

- By reinforcing job security, EPL may enhance productivity performance, as workers will be more willing to co-operate with employers in the development of the production process (Akerlof, 1984).

- To the extent that EPL leads to long-lasting work relationships, it may encourage employers to provide training to workers with potentially beneficial effects on human capital and labour productivity. A better skilled workforce may also increase internal flexibility and thus lead to a better functioning of production activity (Piore, 1986).

- $\quad$ EPL may also be a way to internalise the social costs of dismissals by moving the social burden of re-allocating a worker to another job closer to the firm's profitability criteria (Lindbeck and Snower, 1988).

- However, if these regulations are very strict, as in many European countries, firms may become more cautious about adjusting their workforce with the ultimate effect of reducing labour turnover, e.g. movements from employment to unemployment and from unemployment back to employment (Bertola, 1992).

- In addition, if hiring and firing costs are not transferred into lower wages, total labour costs for the firms increase and this may lead to a lower level of employment, other things being equal.

- The effective coverage or implementation of standard employment protection provisions influences the overall strictness of EPL regulations. For example, in many countries employment protection provisions for workers with regular contracts are often extended to those with fixed-term contracts after a given tenure or number of renewals has been reached. In addition, in some countries, the judicial system appears to have interpreted legislation more strictly than was intended by the law.

- A different degree of strictness of regulation governing permanent versus temporary employment (fixed-term contracts and contracts through temporary work agencies) may affect the structure of employment. Stricter regulations for permanent contracts relative to those for temporary contracts are likely to promote a shift from permanent to temporary employment (as it is occurring in a number of European countries). This has the potential effect of distorting the optimal composition of employment between temporary and permanent contracts. Moreover, those who are able to maintain a permanent contract (often the insiders) will enjoy an even higher level of job security, bringing about an increase in wage pressure (Bentolila and Dolado, 1994). In contrast, those under temporary contracts (often youths and other workers with little work experience or low skills) will bear the brunt of employment adjustment (Saint Paul, 1996).

\subsubsection{What do previous empirical studies suggest about the impact of EPL on the labour market?}

Empirical evidence on the impact of employment protection legislation is mixed, not least because of the lack of suitable data on the enforcement and evolutions of regulations over time (Bertola et al., 1999). A clear distinction exists between the potential effects of EPL on employment turnover as distinguished from the equilibrium level of employment (unemployment) and its compositions (temporary/permanent; youths/prime-age workers etc.). 
- Employment turnover: There is consistent empirical evidence that strict employment protection legislation reduces unemployment turnover. Under strict EPL provisions, the unemployment pool is more stagnant, with fewer people being laid off, but also fewer unemployed people getting a new job. (Bentolila and Bertola, 1990; and Nickell and Layard, 1998). The effects on employment turnover are less clear cut: Bertola and Rogerson (1997) and Boeri (1999) found similar job creation and job destruction rates across countries with different EPL regimes but lower unemployment inflows in flexible labour markets). As stressed in Boeri (1999) and OECD (1999), a possible explanation is that strict EPL may foster job-to-job shifts rather than overall employment turnover because insofar employers and workers will seek direct shifts from one job to another without intervening unemployment spells, in order to avoid the associated dismissal and search costs.

- $\quad$ The level of employment: Some studies (e.g. Scarpetta, 1996) suggest a detrimental effect of strict EPL on the level of employment to working-age population ratios. Nickell and Layard (1998) indicate that this may be partially due to the low participation rates in Southern European countries, which also have strict EPL. However, participation rates may be low, especially amongst the youths, precisely because employment prospects are lower the stricter the EPL system.

- Overall unemployment rate: There is also no consensus as to the overall impact of EPL on unemployment. Part of the disagreement stems from the use of different models. However, disagreement persists even amongst papers using the same indicator (the OECD summary index, see OECD Jobs Study, 1994). While a recent study (Elmeskov, Martin and Scarpetta, 1998) suggests a somewhat more robust effect on unemployment if changes in EPL over the past two decades are taken into account, OECD (1999) could not find a statistically significant effect of EPL on aggregate employment.

- Composition of employment and unemployment: Nickell and Layard (1998), Scarpetta (1996) and OECD (1999) suggest a stronger effect of strict EPL on youth unemployment. Moreover, Grubb and Wells (1993) indicated that strict EPL for permanent workers may encourage firms to shift to temporary workers and more generally foster self employment.

- Persistence of unemployment. By reducing unemployment turnover, strict EPL is also found to slow down the labour market adjustment after an exogenous shock (Jackman et al., 1996; Scarpetta, 1996). Unemployed workers may loose human capital over time and they may exert a lower moderating impact on wages (Blanchard, 1998; Bertola, 1990).

- Dualism. Countries with stronger employment protection for regular contracts tend to display a bimodal tenure distribution with either very short or very long tenures (Boeri, 1999). In countries where fixed-term contracts are liberalised, a large share of employees with fixed-term contracts tend to insulate permanent workers from adjustment (Bentolila and Dolado, 1994), thereby increasing their bargaining power and the corresponding wage pressures.

\subsection{Product market regulation and the labour market}

In the product market too, regulatory provisions are generally motivated on public interest grounds. The main rationales for product market regulations include natural monopoly conditions, externalities, asymmetric information and other types of market failures. However, economic theory also suggests that regulations are generally implemented as a response to pressures of interest groups acting to maximise their (broadly defined) 
incomes. As a result, regulation may be biased towards benefiting interest groups that are better organised and gain more from regulatory interventions. A detailed analysis of these issues is outside the scope of this paper. ${ }^{5}$ It should be noticed, however, that existing regulatory frameworks may be flawed by several (possibly concurring) factors:

- the effects of some regulatory provisions often drift away from the original public interest aims, resulting in the protection of special interest groups; ${ }^{6}$

- regulations and their implementation are sometimes likely to involve costs that exceed their expected benefits; ${ }^{7}$

- technical progress and the evolution of demand can render obsolete in a number of instances the design of existing regulations;

- the progress in regulatory techniques may make it easier than in the past to fine tune regulation, e.g. by separating potentially competitive and inherently imperfect markets.

As a result, in the absence of regulatory reform, existing regulations are likely to be often ineffective and unnecessarily restrictive of market mechanisms in both the product and labour markets, potentially bringing about static and dynamic inefficiencies and losses in social welfare. ${ }^{8}$

The effects of product market regulations on labour market outcomes are complex because they are mediated by market behaviour, industry structure, governance issues and labour market institutions. In general, entry restrictions may originate from explicit legal impediments or limitations on the number of competitors allowed in certain markets as well as from the lack of administrative transparency and/or heavy administrative burdens (socalled administrative regulation). Entry restrictions are also associated with international trade and investment policies that deter competition by non-resident firms either through explicit measures (such as tariffs and legal limitations on foreign ownership) or implicit measures (such as non-tariff barriers and administrative obstacles to the establishment and operation of foreign firms in the domestic market).

Entry restrictions in (otherwise) competitive markets cause production inefficiencies by reducing equilibrium output, moving firm size away from the minimum efficient scale of operation and sheltering inefficient firms from competition by new entrants. Ill-designed entry regulations may cause similar inefficiencies in imperfectly competitive markets by reducing or eliminating actual or potential competition. In addition, entry restrictions constrain the supply of a particular type of capital, entrepreneurial ability (Krueger and Pischke, 1998). Finally, by reducing product market competition and international technology

5. For a discussion of theories of regulation and the related empirical evidence see, for instance, Noll (1989a,b), Winston (1993) and Winston and Crandall (1994).

6. Special interest groups are usually composed of a relatively small number of producers whose individual marginal gains from regulatory interventions are large as opposed to the large audience of consumers, who are typically dispersed and ill-organised and whose marginal gains are individually small. See Peltzman (1989).

7. On the balance of costs and benefits of regulation, see Office of Management and Budget (1998).

8. For a review of the rationale, the status and the potential effects of regulatory reform in OECD countries, see OECD (1997b). 
spillovers, restrictions to foreign competitors are likely to result in lower output and employment growth negatively affecting long-run employment levels ${ }^{9}$.

The inhibition of product market competition has immediate consequences for labour demand both at the firm level and in the aggregate. In general, the wage elasticity of demand will be reduced and the labour demand schedule will shift inwards (Hicks, 1932). In addition, the existence of rents induced by the lack of competition will generally prompt employees to ask for wage premia, especially if they are unionised. ${ }^{10}$ Ceteris paribus, this will induce firms to choose capital-labour ratios higher than in a competitive situation, causing lower employment and additional productive inefficiencies ${ }^{11}$. Therefore, except in some cases of natural monopoly, entry restrictions will generally negatively affect economic efficiency and labour market equilibrium relative to a perfectly competitive benchmark, having important effects on both the overall level of employment and its composition. The level may be negatively affected by distortions in labour demand, upward pressures in wage rates and reduced rates of enterprise creation and survival, the composition by the differential effects of regulatory and administrative provisions on different kinds of enterprises (e.g. sole proprietor vs corporate firms). While the nature and the intensity of these effects will depend also on the features of labour market institutions (e.g. degree of unionisation and centralisation of bargaining mechanisms), their sign will generally remain the same across different institutional settings (Nickell, 1998).

State control over business enterprises, through either ownership or administrative guidance, is a well-known potential source of inefficiency ${ }^{12}$. State ownership generally shelters from the market discipline exercised by private shareholders as well as from the threat of takeover or bankruptcy. Corporate control and monitoring is made more complex than in private enterprises by the supplementary hierarchy of principal-agent relationships involving the interests of politicians and bureaucrats. In addition, the incentives and objectives of public managers are different from those of managers of private firms, often deviating from pure profit maximisation. Searching for political support rather than for support from shareholders, the public manager will generally have a tendency to over-use capital and/or labour, practice less price discrimination (when endowed with market power) and satisfy the non-economic goals imposed (implicitly or explicitly) by the government. These distortions are often favored by the presence of soft budget constraints, due to the availability of state aid and debt guarantees. To the extent that state control shelters inefficient firms from competitive pressures and creates or preserves market power, it can be expected to have the same effects on labour market equilibrium as entry restrictions.

Clearly, in some sectors, such as non-tradeables and/or public utilities, protection from domestic and foreign competitors and labour hoarding by state-controlled firms can maintain employment artificially high for some time, but the related productive inefficiencies are likely to spill over to the entire economy, reducing equilibrium output and employment elsewhere, and the implied budgetary costs are likely to result in an increased tax burden which reins in economic growth. In any case, the increasing integration of OECD economies (both de facto and de jure, through international treaties and agreements) makes it practically impossible to pursue such policies even in the relatively short run.

9. On the effects of international openness on growth, see for instance Edwards, S. (1998).

10. For a survey of theory and evidence on the effects of product market competition on wages, see Nickell (1998).

11. The ratio would not be optimal from a social perspective because the cost of labour to the firm would exceed the opportunity cost of labour to society.

12. For a survey of the relationship between ownership structure and economic efficiency and the related empirical evidence, see World Bank (1995) and Vickers and Yarrow (1991). 


\subsection{Policy interactions}

Labour market outcomes may also be affected by the interaction of EPL with other policies and labour market institutions as well as with product market regulations. The first type of interactions has only recently been analysed in the empirical literature. Bertola and Rogerson (1997) and Elmeskov, Martin and Scarpetta (1998) suggest that higher employment turnover costs due to more stringent employment protection legislation are associated with higher unemployment in countries with intermediate bargaining systems where wages do not fully adjust. Moreover, Buti et al. (1998) point out that stringent EPL may act as a substitute for unemployment insurance benefits. Under this hypothesis, countries might opt for either generous unemployment benefits with lax EPL or vice versa. They argue that a combination of very generous benefits with strict EPL would lead to higher structural unemployment. However, the authors use simple bivariate correlation in their analysis, and Elmeskov, Martin and Scarpetta (1998) found no significant evidence of this interaction in an econometric analysis of the determinants of structural unemployment for a large sample of OECD countries.

Potential interactions between EPL and product market regulations are manifold and may have significant effects on labour market outcomes. For instance, the possibility that lower employment levels in monopolistic sectors is compensated by higher employment in other more competitive sectors depends on the flexibility of wages in these other sectors to accommodate higher employment of "released" workers. If wages do not fully adjust because of high reservation wages, high wage floors and/or nation-wide wage agreements, then lower aggregate employment is likely to result. Moreover, the insider power of workers employed in firms sheltered from competitive pressures (either by legal, administrative and trade restrictions or public ownership) can be compounded by the presence of unduly restrictive EPL, pushing up wage premia and lowering equilibrium employment. Similarly, the existence of thresholds for the application of EPL to collective or individual dismissals may affect the minimum efficient scale of firms (after accounting for the cost of regulations) and favour particular kinds of company structures (such as sole proprietor firms). This effect can be reinforced (or weakened) by a profile of administrative burdens favouring (or discouraging) the creation of individual firms. Therefore, on the whole, different combinations of the regulatory regimes in the labour and product market can be expected to result in different labour market equilibrium configurations, potentially distorting the optimal level and composition of employment (e.g. between dependent and self-employment). At the same time, the effects of regulatory reform are likely to be different depending on the initial combination of regimes and on the sequencing of the reforms in the two markets. To date, empirical evidence on the relationship between labour and product market regulations across countries and on their effects on labour market outcomes has been lacking ${ }^{13}$. The next sections of this paper provide an initial attempt in this direction.

\section{Assessing differences in regulatory regimes across countries}

From a theoretical standpoint, there is a strong presumption that ill-designed regulatory regimes, which unduly restrict labour and product market competition and distort governance mechanisms may reduce equilibrium employment and affect its composition. However, since regulations are usually introduced in second-best situations related to purported market failures, their actual impact on labour market outcomes can only be ascertained empirically, attempting to relate differences in regulatory regimes over time and/or across countries to the observed patterns of employment.

13. For a somewhat crude attempt to study the combined effects of labour and product market regulations on economic growth in European countries, see Koedjik and Kremers (1996). 
The analysis of the linkage between regulation and labour market performance has generally stumbled on the lack of synthetic and comparable measures of the stance of regulation across countries. In this paper, a large set of information on product and labour market regulations at the economy-wide and sectoral levels was used to establish crosscountry patterns of regulation and to construct internationally-comparable indicators of regulation (see below). Information on labour and product market regulations consists of a multitude of sector-specific or general-purpose provisions. Although, in principle, crosscountry comparisons of individual provisions are possible, the analysis of the linkages between regulation and labour market performance is meaningful only after some aggregation has been made. Therefore, information that was essentially scattered and qualitative had to be measured in quantitative terms and summarised in a uniform and, as much as possible, objective way across countries.

Cross-country comparisons of regulatory regimes were performed using a multidimensional approach. The focus was set on summary indicators synthesising several dimensions of labour or product market regulation. These indicators were obtained (using a data-based aggregation methodology) as a combination of first level, more detailed, indicators of individual regulatory provisions. The main advantage of this approach is that the relative positions of countries evaluated along multiple dimensions are unlikely to be as sensitive to data problems as those positions established on the basis of multiple comparisons of unidimensional indicators.

The overall regulatory environment was analysed along four main axes, distinguishing between (a) the control of resources and market behaviour by the state; (b) barriers to entrepreneurial activity; (c) barriers to trade and investment; and (f) employment protection legislation for permanent and temporary workers. In order to organise and simplify the data, a multiple-tier structure of indicators was established, featuring at the bottom the individual provisions, at the first level the aggregation of these provisions into indicators of single dimensions of regulation (first-level indicators), at the next level the aggregation of these first-level indicators into the four axes of regulatory intervention (summary indicators) and at the top the two indicators of overall regulation in the product and labour markets. ${ }^{14}$

In order to reduce discretion, multivariate data analysis techniques were used to identify regulatory regimes and to aggregate first-level indicators into the summary measures of product and labour market regulation. Cluster analysis made it possible to group countries sharing similar regulatory environments. Starting from the values of the indicators, this technique builds similarity matrices whose entries are the (Euclidean) distances resulting from pair-wise comparisons of the individual indicators across countries. An algorithm based on the sequential minimisation of these pair-wise distances progressively reduces the dimension of the matrix by clustering together countries with minimum distances (so-called single linkage clustering). The results of this clustering algorithm can be inspected by means of a variety of graphical representations, such as tree-like diagrams called "dendrogram". Factor analysis made it possible to aggregate the first-level indicators according to an "objective" weighting procedure that maximises in a parsimonious way the proportion of the total

14. The first-level indicators were obtained by turning qualitative information into numerical format using a system of codes (e.g. the presence or the absence of a regulatory provision were assigned different codes) and by ranking the resulting data on individual regulatory provisions on an identical 0-6 scale reflecting the implied degree of restrictiveness of the provisions (from least to most restrictive). Around 70 first-level indicators have been used to construct the two summary indicators of product and labour market regulation. 
variance in the data explained by the resulting indicators ${ }^{15}$. This approach yields a minimal set of indicators that best summarises the variance of regulation across countries, with no priors as to which regulatory provisions may be most influential on performance and no arbitrary weights involved in the aggregation of the first-level indicators. Nonetheless, given the qualitative nature of most of the basic information on regulation, some degree of subjectivity was inescapable in the construction of the first-level regulatory indicators. A precise description of the data sources and methodologies used in the construction of first-level and summary indicators is in Nicoletti, Scarpetta and Boylaud (1999).

Prior to describing differences in product and labour market regulation across countries a few cautionary notes are in order. First, the indicators of product market regulation are based on a very preliminary set of data. Second, they only cover formal regulations, leaving out other kinds of regulatory interventions such as administrative guidance or self-disciplinary measures of professional associations. Third, no attempt was made to measure the quality of product market regulations and the extent to which they are actually enforced. As a result, the ranking of countries provided by the summary indicators should be considered only as an approximation of the strictness of product market regulations across the OECD.

\section{$2.1 \quad$ Indicators of labour market regulation}

As a step ahead in the analysis of the effect of EPL on labour market performance, this study uses a set of indicators of employment protection legislation concerning both regular and temporary workers. ${ }^{16}$

\subsubsection{Regulation of permanent employment}

We focus on the strictness of the following individual dismissal protections for workers with permanent contracts: i) procedural inconveniences that employers face when trying to dismiss a worker; ii) notice and severance payments; and iii) prevailing standards of and penalties for "unfair" dismissals. Table 1 presents the different aspects that have been considered within these three broad categories.

15. For a similar application of factor analysis in economic research, see Berlage and Terweduwe (1988).

16. Basic indicators of EPL can be found in (OECD, 1999). 
TABLE 1 EPL Indicators for permanent workers

\begin{tabular}{|c|c|c|}
\hline \multirow{2}{*}{$\begin{array}{l}\text { Regular procedural } \\
\text { Inconveniences }\end{array}$} & \multicolumn{2}{|c|}{ Procedures } \\
\hline & \multicolumn{2}{|c|}{ Delay to start a notice } \\
\hline \multirow{6}{*}{$\begin{array}{c}\text { Notice and } \\
\text { Severance pay } \\
\text { For no-fault individual } \\
\text { dismissals }\end{array}$} & \multirow{3}{*}{ Notice period after } & At 9 months \\
\hline & & At 4 years \\
\hline & & At 20 years \\
\hline & \multirow{3}{*}{ Severance pay after } & At 9 months \\
\hline & & At 4 years \\
\hline & & At 20 years \\
\hline \multirow{4}{*}{ Difficulty of dismissal } & \multicolumn{2}{|c|}{ Definition of unfair dismissal } \\
\hline & \multicolumn{2}{|c|}{ Trial period } \\
\hline & \multicolumn{2}{|c|}{ at $20 \mathrm{y}$} \\
\hline & \multicolumn{2}{|c|}{ Reinstatement } \\
\hline
\end{tabular}

Procedural requirements refer to the process that has to be followed from the decision to lay off a worker to the actual termination of the contract. They include: the delay before the notice of dismissal can start (for example, because there has to be a series of previous warnings); whether a written statement of the reasons for dismissal must be supplied; whether a third party (such as a works council or the competent labour authority) must be notified or consulted; and whether dismissal cannot proceed without the approval of a third party.

Notice and severance pay may differ for blue-collar and white-collar workers, or for dismissals for personal reasons and for economic redundancy (see OECD, 1999). In general both notice and severance payments tend to be higher for white-collar workers and for redundancies than for blue-collar workers. In this study we consider an average of regulations affecting the two categories of workers.

Under "difficulty of dismissal" the analysis includes the length of the trial period because during this period a dismissal cannot be contested for its unfairness: the shorter the trial period the stricter is the regulation on unfair dismissal. Moreover, account is taken of cases where the employer cannot demonstrate appropriate previous efforts to avoid the dismissal, or when social, age or job tenure factors have not been considered. Finally, account is taken of the fact that, in some cases, labour courts may require employers to reinstate a worker affected by an unfair dismissal, or award high compensation payments in excess of regular severance pay.

\subsubsection{Regulation of temporary forms of employment}

As discussed below, many OECD countries have reformed regulations for temporary employment, by either allowing fixed-term or TWA (temporary work agency) contracts, or by liberalising their use. Indicators of the stringency of EPL for temporary contracts are reported in Table 2. They refer to: i) the "objective" reasons under which they could be offered; ii) the maximum number of successive renewals; iii) and the maximum cumulated duration of the contract. Most Anglo-Saxon countries have always allowed the use of temporary contracts without any significant restrictions. Currently, some countries continue to list specific situations that may, however, go beyond "objective", time-limited tasks (e.g. business start-ups or workers in search of their first job). There are also significant differences on the maximum duration of fixed-term contracts. While in Canada, Ireland, the United Kingdom and the United States there are no limitations on the number of renewals, in 
a number of other countries this is only the case if separate valid "objective" reasons can be given for each new contract. In these cases, after successive renewals labour courts may be asked to examine the validity of the request for a further contract. In this respect, a number of countries facilitate the use of fixed-term contracts by setting by law the maximum number of renewals (e.g. Belgium, France, Germany and the Netherlands).

\section{TABLE 2 EPL Indicators for temporary workers}

\begin{tabular}{|c|c|c|}
\hline \multirow{4}{*}{ Temporary } & \multirow{2}{*}{ Fixed-term contracts } & Valid cases other than the usual "objective" \\
\cline { 3 - 3 } Contracts & & Maximum number of successive contracts \\
\cline { 3 - 3 } & & Maximum cumulated duration \\
\cline { 3 - 3 } & \multirow{2}{*}{$\begin{array}{c}\text { Temporary work agency } \\
\text { ( TWA) employment }\end{array}$} & Types of work for which is legal \\
\cline { 3 - 3 } & & Restrictions on number of renewals \\
\cline { 3 - 3 } & &
\end{tabular}

\subsubsection{Summary indicators of employment protection legislation over the past decade}

Figure 1 plots the summary indicators of EPL for permanent and temporary workers for 1990 and for 1998. In countries along the diagonal the summary EPL indicator did not change over the 1990s; in those above the diagonal regulations became tighter in the past decade; and in those below the diagonal regulations were relaxed.

Broadly speaking, there has been a tendency for a significant deregulation of temporary contracts, while only modest changes have been recorded for permanent contracts. Only Finland, Portugal and Spain have significantly eased regulation for permanent workers. In Finland both the delay to the start of notice and the notice period itself were reduced; Portugal tightened its regulation by increasing the amount of mandated severance payments; and in Spain new permanent contracts were introduced with lower (albeit still high) severance payments. The Netherlands eased restrictions on dismissals, widening exemptions from general dismissal law but increased the minimum notice period and decreased the maximum periods. In the process of harmonising notice periods for blue-collar and white-collar workers, Germany increased the length of notice for long-tenure workers. By contrast, mandated notice periods seem to have decreased somewhat in Spain, Sweden and Finland. 


\section{Figure 1 Indicators of the strictness of employment protection legislation, 1990-98}

Panel A. Regular and temporary contracts

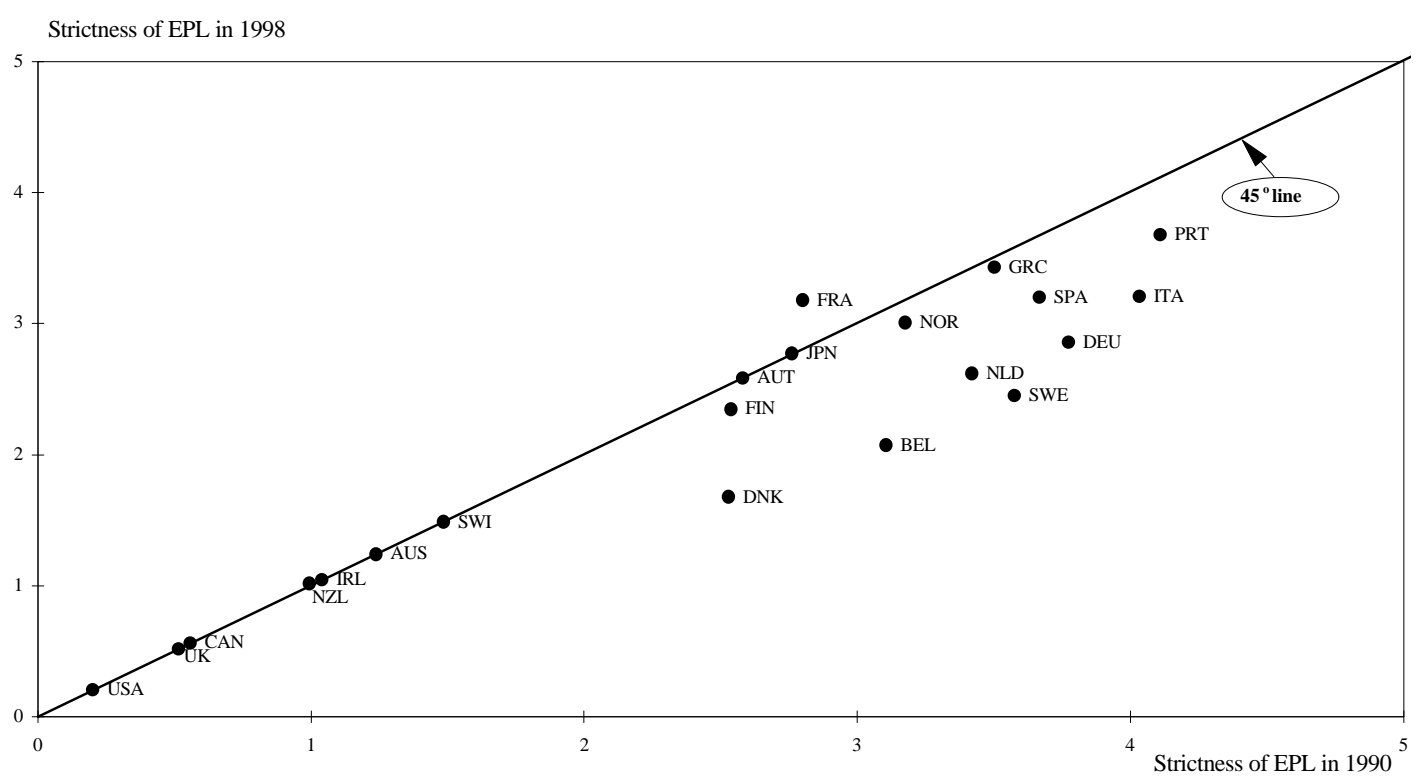

Panel B. Regular contracts

Panel C. Temporary contracts
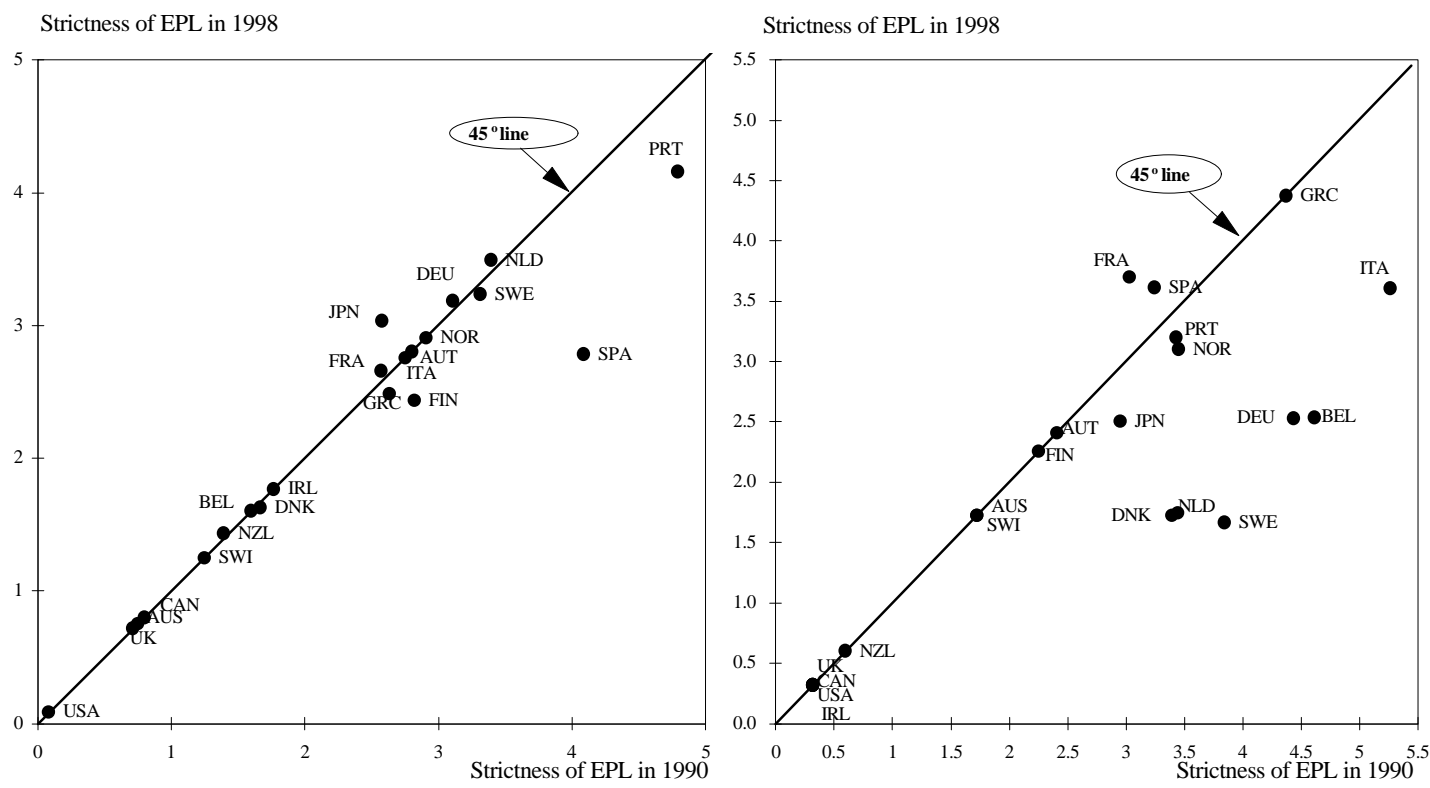

Note:

1. The indicator is the weighted sum of indicators referring to several aspects of employment protection legislation for regular contracts as well as for fixed-term and TWA contracts. The original indicators range from 0 (least restrictive) to 6 (most restrictive). The weights are extracted from a factor analysis of original indicators.

Source: The summary indicators are from Nicoletti, Scarpetta and Boylaud (1999).

In a number of countries (e.g. Japan, Germany, Italy Belgium, Finland, New Zealand and Sweden) fixed-term contracts can now be used in a wider range of situations than at the beginning of the 1990s. The maximum number of successive renewals has been extended in Germany, Italy, Belgium, the Netherlands and Sweden. Increases in the maximum cumulative duration of successive contracts have been legislated in Germany, Italy, Belgium, the Netherlands, Portugal and Sweden. In Spain, fixed-term contracts were 
liberalised in the late 1980s, and, following the dramatic increases in their use, some restrictions have been re-imposed recently. In Denmark and Sweden, all restrictions on the types of work for which TWA employment is legal have been removed and in Italy and Spain TWAs have become legal for certain types of work while having previously been illegal in all circumstances. Other relaxations on the range of jobs for that TWA are allowed have taken place in Denmark, Germany, the Netherlands, Norway and Japan. In Denmark restrictions on the number of renewals have been removed; and the maximum duration of successive contracts has been increased in Germany, Belgium, Denmark, Portugal and the Netherlands. Other countries took limited or no action to reform this kind of labour market regulations.

\subsection{Indicators of product market regulation}

Product market regulation was analysed along three main axes : (a) direct state control of economic activities, through state shareholdings or other types of interference in the decisions of business sector enterprises and the use of command and control regulations; (b) barriers to private entrepreneurial activity, through legal limitations on access to markets or administrative burdens and opacities hampering the creation of businesses; and (c) regulatory barriers to international trade and investment, through explicit legal and tariff provisions or regulatory and administrative obstacles. The country rankings resulting from the corresponding summary indicators are shown in Figure 2.

The analysis of direct state control was based on five first-level indicators concerning (i) the presence of state-controlled enterprises in business (two and three digit) industries, (ii) the presence of special voting rights in private enterprises, (iii) the degree of control exercised by legislative bodies over state-owned business sector enterprises, (iv) the propensity to resort to command and control, rather than incentive-based, regulatory provisions and $(\mathrm{v})$ the extent of public ownership in the non-agricultural business sector ${ }^{17}$. Based on these indicators, hierarchical cluster analysis identified two large groups of countries. A group of "incentive-based" countries, including most common-law countries, Japan, Germany and Sweden, characterised by a below-average degree of state control and a group of "command-based" countries, including the other OECD countries. Within these groups, countries differ mainly by the extent of government interference in the operation of private businesses (e.g., special voting rights and use of command and control regulations). Correspondingly, two main underlying factors were identified in the data, clearly separating out government interference in private business operation from the other indicators of state control. The summary indicator of direct state control shows considerable variation across countries and identifies the US, the UK, Canada, Sweden and Japan and New Zealand as the countries with relatively low state control. At the other extreme, Greece, Italy and Belgium are identified as the countries with the highest state control.

17. Indicators (i)-(iv) are based on national sources (see Nicoletti, Scarpetta and Boylaud, 1999a); indicators (v)-(vi) drew on Centre Européen des Entreprises à Participation Publique, CEEP (1997); for non-European countries on Gwartney and Lawson (1997). 
Figure 2. Summary indicators of product market regulation ${ }^{1,2}$
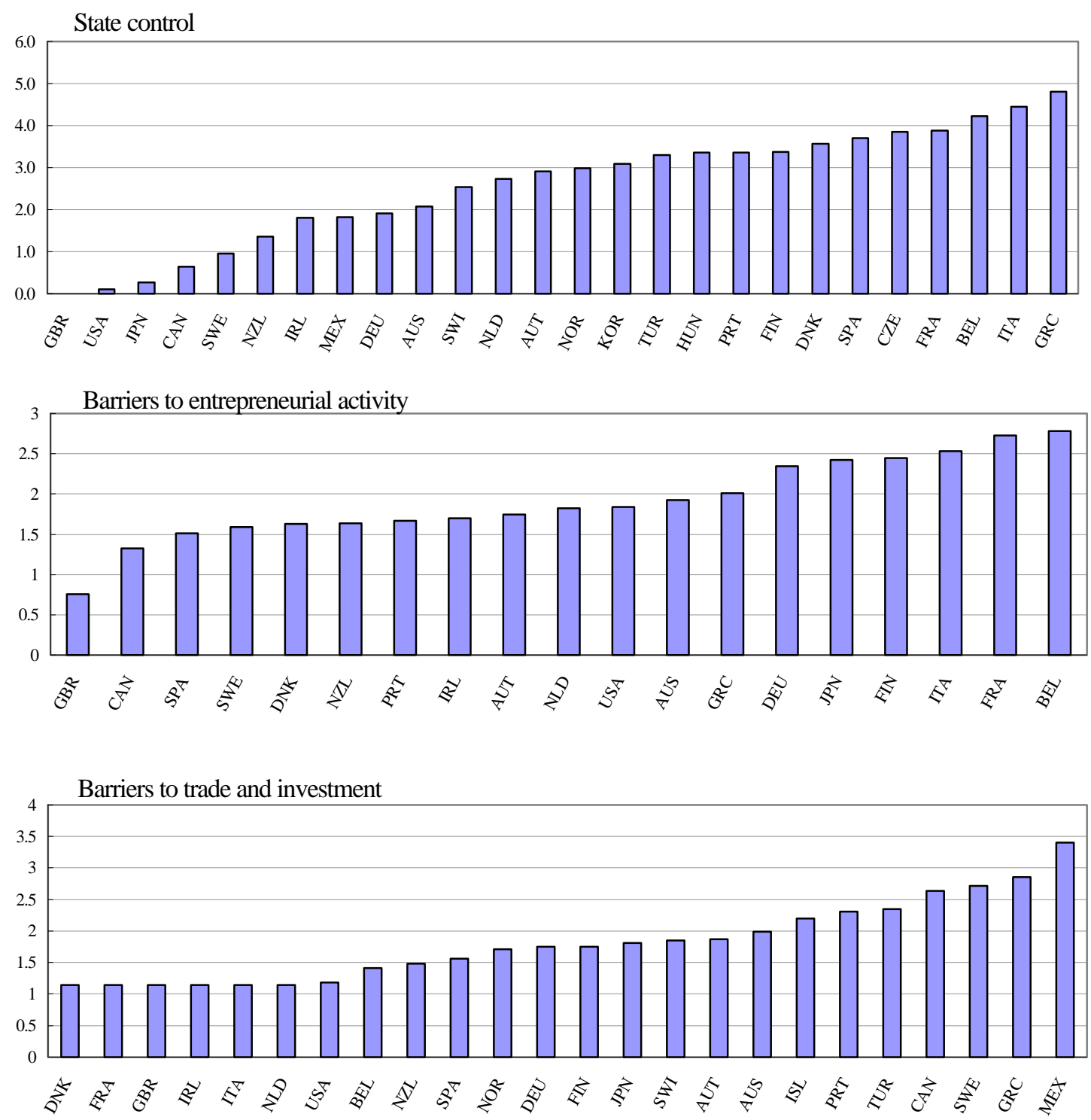

1. Country scores reflect the results of factor analysis. Summary indicators are obtained weighting factors by their relative contributions in explaining the total variance of the factors. All variables were cast in 0-6 scale from least to most regulated.

2. Factor analysis applied to basic indicators.

The analysis of regulatory barriers to entrepreneurial activity was also based on six first-level indicators concerning (i) the features of the licensing and permit system, (ii) initiatives to reduce administrative burdens, (iii) administrative transparency, (iv) legal limitations to entry in (two and three digit) business industries, and administrative burdens on the creation of (v) corporations and (vi) sole proprietor businesses ${ }^{18}$. Countries proved to be relatively dispersed along the various dimensions of this axis of regulatory intervention and

18. Indicators (i)-(iv) are based on national sources (see Nicoletti, Scarpetta an Boylaud, 1999); indicators (v)-(vi) drew on Logotech, S.A. (April 1997), Etude comparative internationale des dispositions légales et administratives pour la formation de petites et moyennes entreprises aux pays de l'Union Européenne, les Etats-Unis et le Japon, Projet EIMS 96/142; and Bureau of Industry Economics (1996). 
no readily interpretable groupings could be established by means of cluster analysis. Three main factors could be identified relating to legal barriers, administrative burdens on the creation of businesses and more general barriers created by administrative procedures. The summary indicator suggests that, overall, barriers to entrepreneurship are less variable than state control across countries. According to this indicator, countries with the lowest barriers include the UK, Canada and Spain, while the highest barriers are found in Belgium, France and Italy. The average ranking of the United States reflects low legal barriers but relatively heavy administrative procedures.

The analysis of barriers to international trade and investment was based on five first-level indicators (i) legal and administrative barriers to foreign ownership of businesses, (ii) the existence of explicit provisions discriminating business activity on the basis of nationality, (iii) nationality discrimination implied by regulatory and administrative procedures, (iv) average trade tariffs and (v) the incidence of non-tariff barriers to trade ${ }^{19}$. Due to the limited coverage of some of these indicators, the focus had to be restricted on a few issues, not necessarily fully representative of the countries' trade and investment policies ${ }^{20}$. Cluster analysis classified countries in two broad groups: a highly homogeneous group comprising the majority of European countries and the United States; and an idiosyncratic group of countries, partly characterised by less open trade policies, including five European countries (Norway, Sweden, Greece Switzerland and Portugal), the australasia countries (New Zealand and Australia), Japan and Turkey. Two main discriminating factors were identified: tariff and regulating barriers, including indicators (ii) (iii) and (iv), and other barriers, including indicators (i) and (v). The resulting summary indicator ranks France, Italy, the UK, Denmark, Ireland, the Netherlands and the United States as being the most open, while Canada, Sweden, Greece and Mexico appear to have a relatively high level of barriers.

Using these summary indicators three patterns of overall product market regulation could be established: a mostly common-law group, characterised by a combination of relatively liberal inward and outward-oriented regulatory policies; a mostly continental European group (including also Australia), characterised by relatively liberal outwardoriented policies, but more interventionist and restrictive inward-oriented policies; and an idiosyncratic group composed of countries with widely different inward-oriented policies but sharing relatively closed outward policies (including Canada, Sweden, Portugal and Greece). The summary indicator of product market regulation suggests that the countries having the most liberal regulatory approaches are the United Kingdom, the United States and, to a lesser extent, New Zealand Ireland and Japan, while the most restrictive approaches are found in Greece and, to a lesser extent, Italy and Belgium (Figure 3). In order to interpret these results correctly, it should be reminded that only formal and explicit regulations have been taken into account, leaving out all other informal procedures through which the government or trade associations can influence economic behaviour as well as possible differences in enforcement.

19. Indicators (i)-(iii) are based on national sources (see Nicoletti and Scarpetta, 1999a); indicators (iv)-(v) drew on OECD (1997a).

20. In order to increase the coverage, missing values for some of the EU countries were set equal to the values suggested by EC provisions. 
Figure 3. Overall indicator of product market regulation ${ }^{1}$

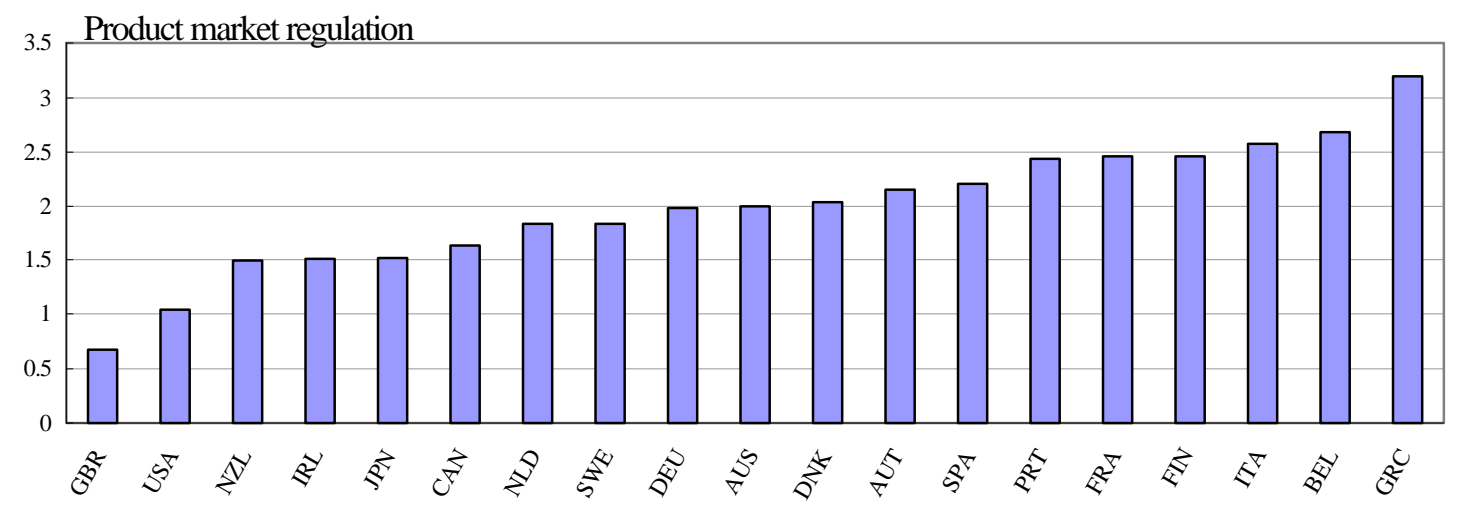

1. Factor analysis applied to summary indicators of state control, barriers to entrepreneurial activity and barriers to trade and investment.

\section{The relationships between regulations in the labour and product markets}

The analysis of the various dimensions of regulation in the product and labour markets can be combined to investigate the features of the overall regulatory environment across OECD countries. Employment protection regulations and product market regulations may be correlated across countries and contribute to an overall regulatory framework which influences labour market performance. Interestingly, the overall indicators of product and labour market suggest that, in general, restrictive product market regulations are matched by analogous EPL restrictions. There is a strong statistical correlation between the two overall indices of regulation across countries (correlation $=0.76$, significant at the $1 \%$ level).

To shed further light on this issue, we use cluster analysis to construct groups of countries that share common patterns across the two sets of regulations and try to interpret these groups. The analysis was performed using as basic data the aggregations of the firstlevel indicators (summary indicators) obtained by means of factor analysis. For the product market we included the summary indicators of (i) state control; (ii) barriers to entrepreneurial activity; and (iii) barriers to trade and investment. For the labour market we included the summary indicators of (i) EPL for permanent workers; and (ii) EPL for temporary workers.

The dendrogram in Figure 4 identifies patterns of behaviour among the OECD countries $^{21}$. Four clusters can be identified:

21. The dendrogram is a graphical representation of all the possible groups of similar observations that can be obtained from cluster analysis. The graph is tree-structured and should be read left to right (roots to top). In the beginning, the number of groups is equal to the number $(\mathrm{N})$ of observations (the roots). Then the country pair with the lowest distance forms the first group. In the following steps, pairwise comparisons between all remaining countries and between these and the first group are performed and new groups are formed. The points at which two countries (or groups of countries) join are called knots and are numbered progressively from $\mathrm{N}$ to $(\mathrm{N}+\mathrm{K})$, where $(\mathrm{N}+\mathrm{K})$ is the total number of groups and the $(\mathrm{N}+\mathrm{K})$ th knot corresponds to the group containing all observations (the top of the tree). As hierarchical clustering unfolds, an index of inter-group similarity is calculated at each juncture. The higher the index the more dissimilar are the observations contained in the groups being joined. Since eventually all countries are grouped together, at some knot rather disparate groups will be forced to join, implying a large jump in the index. The optimal number of groups is often situated at such junctures. 
- The first includes most Southern European countries (France, Italy, Greece and Spain) which combine strict regulation on both the labour and product markets;

- The second includes continental European countries, which share relatively restrictive product market regulations, but can be further split in two sub-groups according to the EPL stance: Belgium and Denmark being less restrictive than Germany, Austria, the Netherlands, Finland and especially Portugal;

- The third group includes common-law countries, which are characterised by a relatively liberal approach in both the labour and product markets (the United States, the United Kingdom, Canada, Ireland, Australia and New Zealand).

- Finally, Japan and Sweden are outliers in the sense that they combine relatively restrictive labour market regulations with relatively few (formal) restrictions in the product market.

Figure 4. Dendrogram of product market regulation and EPL
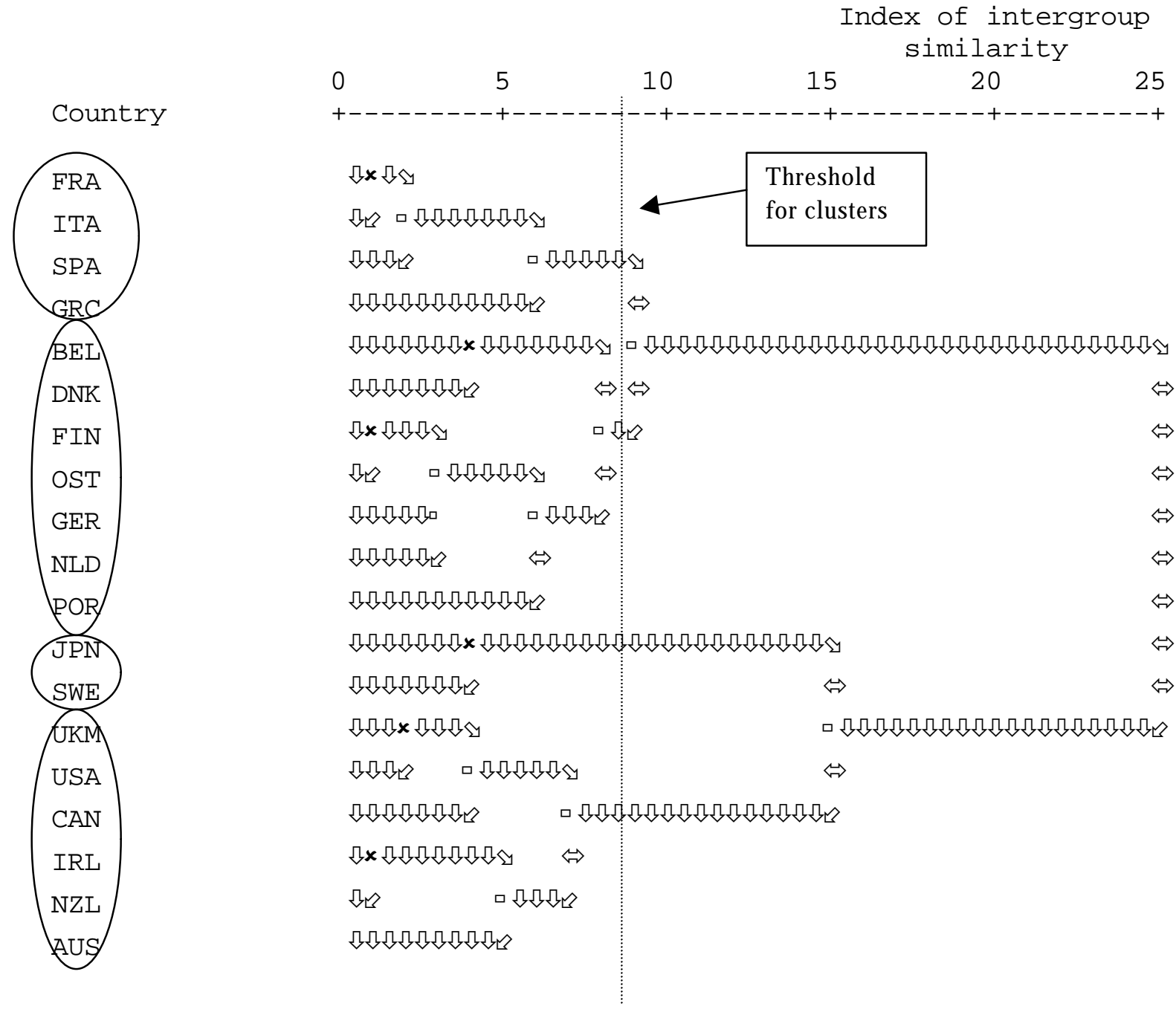


\section{Regulations in the product and labour markets and labour market performance}

As stressed in the introduction, the OECD countries display large differences in labour market performance despite underlying market forces that have led to increasing economic integration. To some extent, differences in performance may be due to macroeconomic factors, such as differences in cyclical developments and the inertia deriving from the historical divergence of economic policies across countries, which resulted in different equilibrium configurations. However, the widespread implementation of policies aimed at ensuring macroeconomic stability for sustainable growth, in Europe and in other OECD countries, suggests that part of the performance gaps must be related to other factors. These may include a policies, regulations and institutions affecting directly the labour market as well as the regulatory environment characterising the product market. In this section we focus on three aspects of labour market performance that seem to be particularly sensitive to regulations: 1) the overall employment rate in the business sector (business sector employment divided by the working age population); 2) the incidence of self-employment in total business sector employment; and 3) the incidence of temporary in total employment.

\subsection{Bivariate correlations between regulations and employment patterns}

Figure 5 plots the business sector employment rates in the OECD countries (average of the 1990-1995 period), while Figure 6 shows their evolution over the past two decades. There are clearly significant differences in the share of working age population which is employed in the business sector across the OECD countries: it ranges from about 40 per cent in Spain to up to 70 per cent in Switzerland. These differences are related to overall labour market conditions in different countries, which also affect the decision of certain groups (youths, women in particular) to enter in the labour market, as well as to the role of the state as an employer in the economy. Figure 6 also suggests very different trends over time. North American countries, Japan, the UK, the Netherlands and some other smaller countries in Europe have shown a positive trend over the past two decades. In contrast, some of the Nordic countries have shown a significant fall in the early 1990s (due to the sharp economic crisis there) and most European countries have shown stable or slightly declining trends. 
Figure 5 Employment rate in the business sector, 1990-95

(per cent of total working-age population)

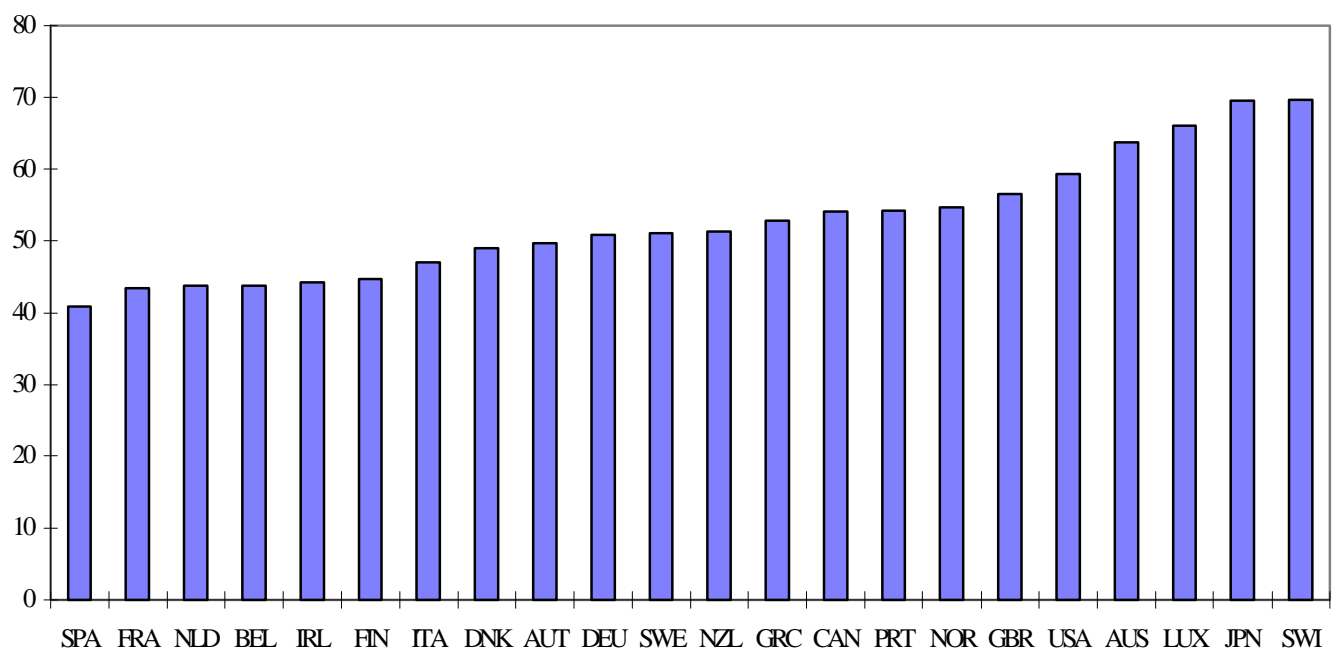


Figure 6 Trends in employment rate across the OECD countries, 1982-95
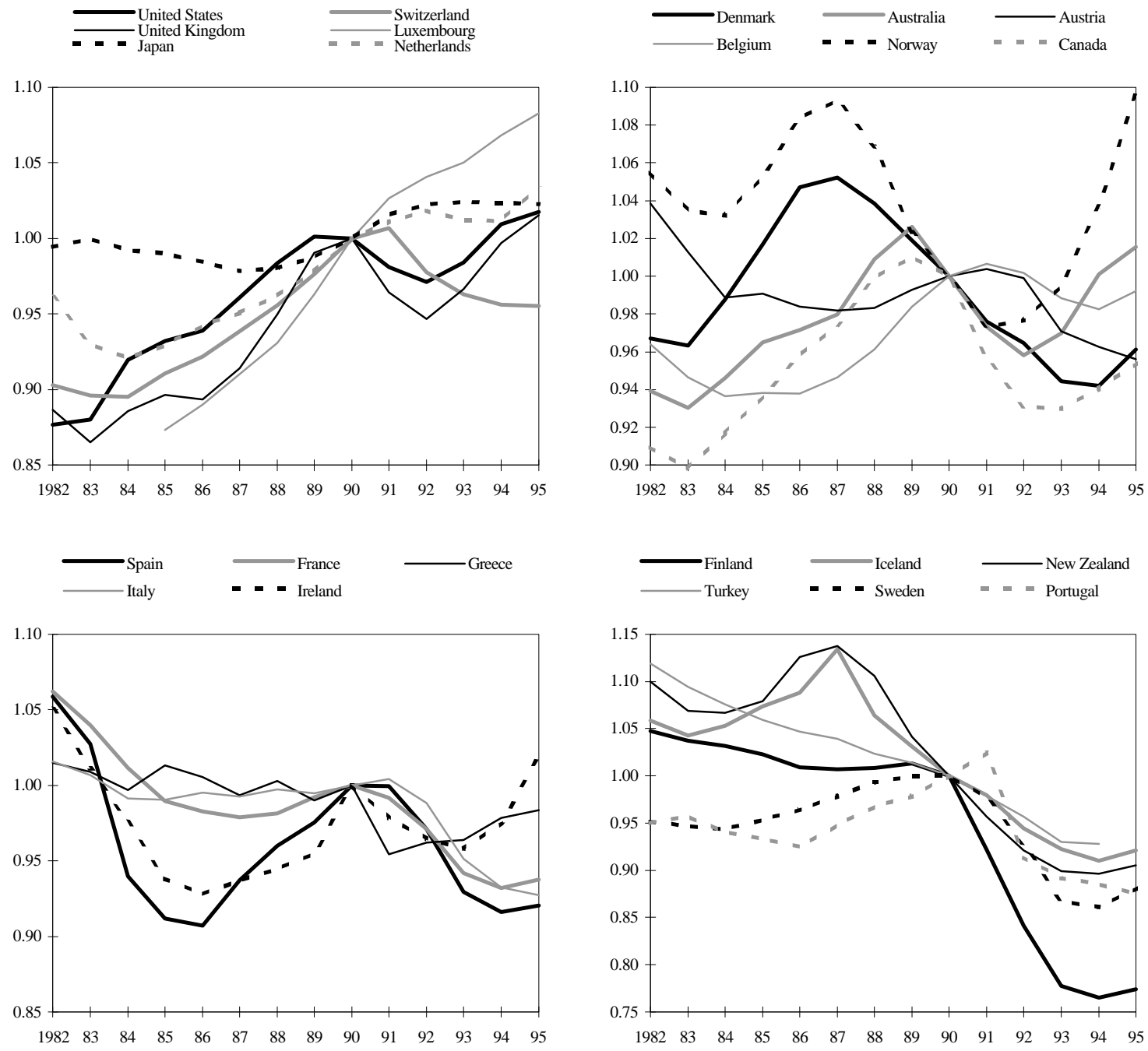
The OECD countries also show marked differences in the composition of employment. Figure 7 plots the share of self-employment in total employment across countries and across the main sectors of the economy. Despite significant cross-sectoral differences, some common patterns can de identified. There is a clear tendency for Mediterranean countries to have a higher incidence of self employment in all sectors of the economy, and particularly so in the service sector, while the proportion of self employment is much lower in continental Europe and in most English-speaking countries. The agricultural sector stands apart in this respect insofar as a larger than average proportion of self employed is found in countries with a relatively lower overall degree of development (Turkey, Greece, Ireland).

The proportion of temporary employment also varies a great deal across countries and over time. Figure 8 plots the incidence of temporary employment in total employment in 1985 and in 1997. There has been a tendency in the majority of OECD countries to increase the proportion of temporary employment in total employment, and particularly so in Spain where almost one-third of total employment was under temporary contract in 1997. It is more difficult to find clear geographical divides as the incidence of temporary employment is relatively high in some European countries as well as in Australia. ${ }^{22}$ Table 3 also reveals significant differences in the evolution of employment over the current recovery period. In contrast with patterns recorded in previous recovery, the growth in temporary employment has played a major role in total employment developments, compensating falling (or stable) permanent employment in a number of European countries such as Austria, France, Germany, Italy, Portugal and Sweden. In the other countries a more balanced combination of employment has been observed with both permanent and temporary jobs being created.

22. It should be stressed, however, that the nature of temporary contracts in the latter is different from most of those in Europe: temporary contracts in Australia are "casual" jobs offered to young workers who prefer to bargain the non-coverage of pension and health insurance for a higher pay. 
Figure 7 Share of self employment, 1995

(percentage of total employment in the business sector)
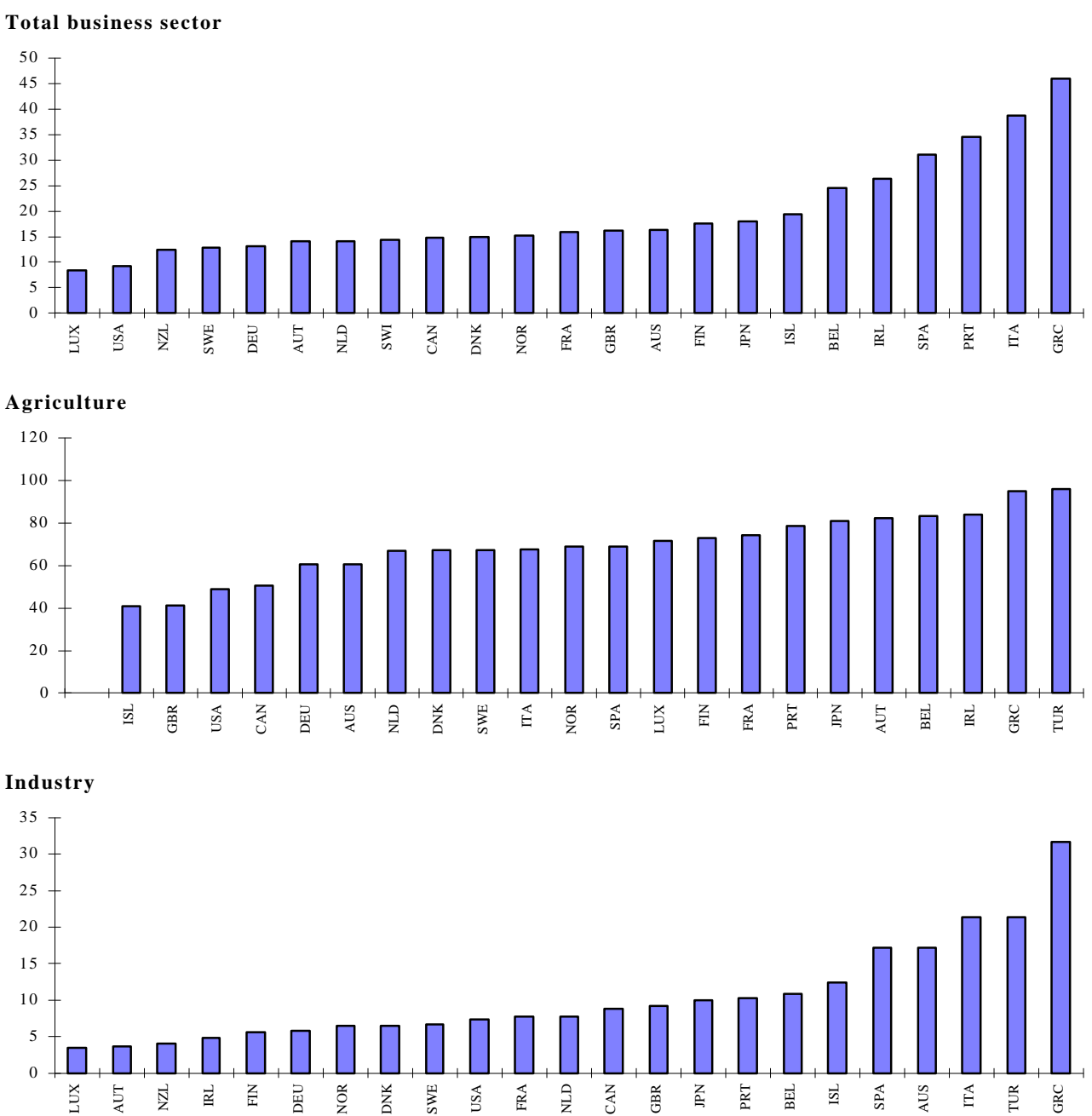

Services

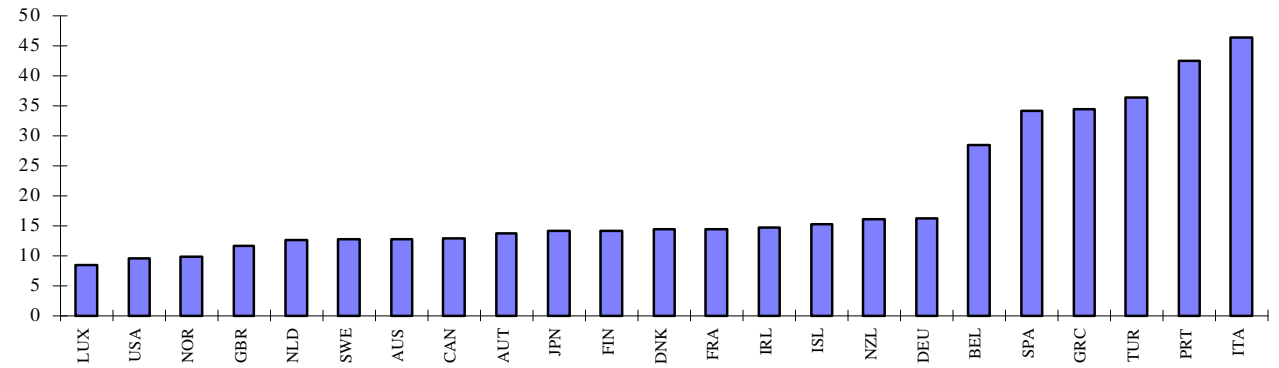

Source: OECD database. 
Figure 8 Share of temporary employment. 1985-97

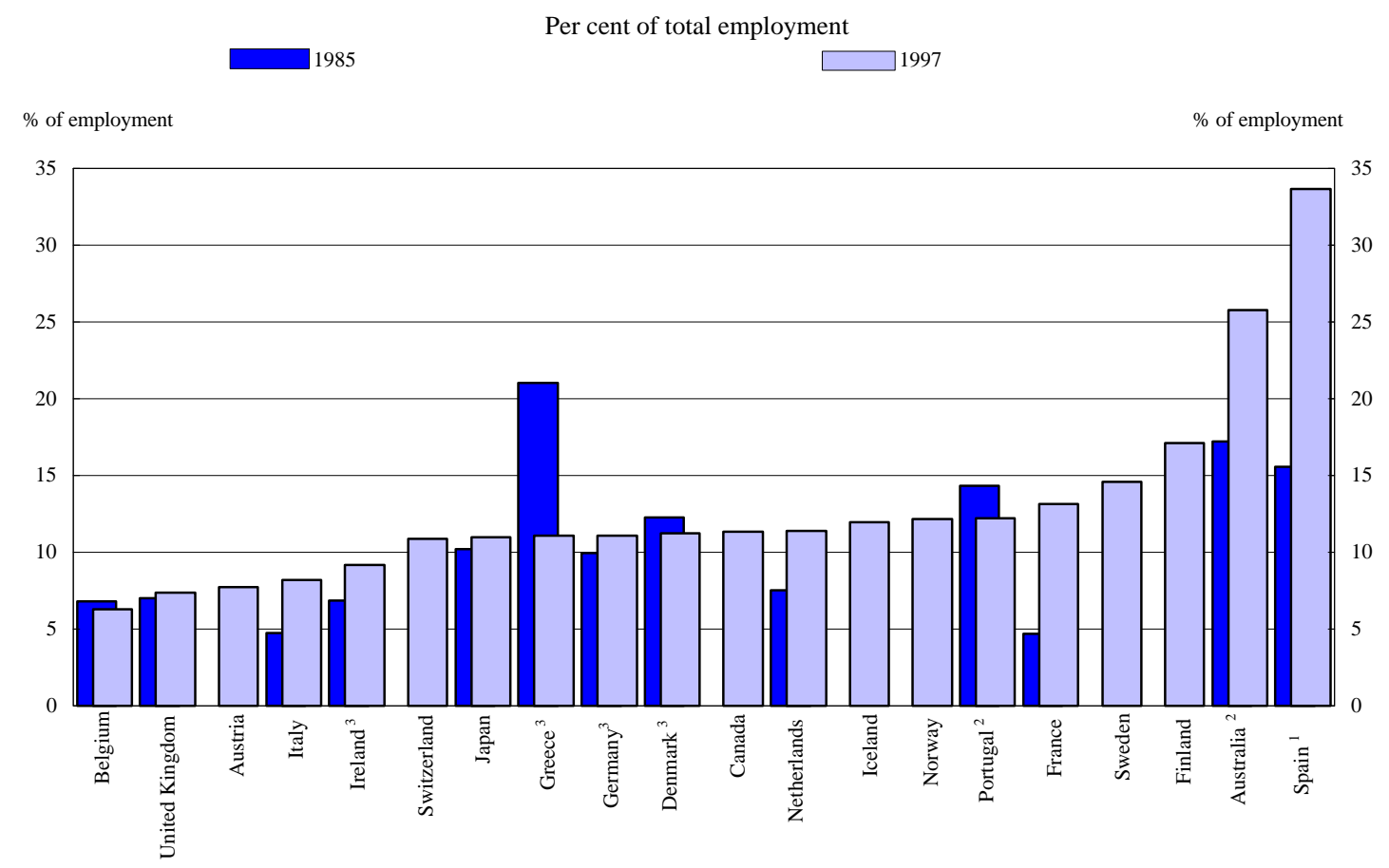

Notes:

1. 1987 and 1997.

2. 1986 and 1997.

3. 1985 and 1996.

Source: OECD Employment Outlook, 1998. 
Table 3 Changes in permanent and temporary employment, 1993-97

\section{Average annual change as a percentage of total employment}

1993-97

\begin{tabular}{|c|c|c|c|c|c|}
\hline & $\begin{array}{c}\text { Total } \\
\text { employees }\end{array}$ & Permanent & Temporary ${ }^{1}$ & $\begin{array}{c}\text { Share of } \\
\text { temporary in } \\
\text { employment } \\
1997\end{array}$ & $\begin{array}{c}\text { Share of temporary } \\
\text { in total } \\
\text { employment } \\
\text { growth }\end{array}$ \\
\hline Australia & 2.6 & 1.1 & 1.4 & 25.8 & 55.6 \\
\hline Austria $^{2}$ & -0.7 & -1.5 & 0.8 & 7.8 & \\
\hline Belgium & 0.9 & 0.5 & 0.3 & 6.3 & 41.0 \\
\hline Czech Republic $^{2}$ & -0.2 & 0.0 & -0.2 & 7.9 & \\
\hline Denmark $^{3}$ & 1.3 & 0.9 & 0.3 & 11.2 & 27.6 \\
\hline Finland $^{2}$ & 3.0 & 2.2 & 0.8 & 17.1 & 26.7 \\
\hline France & 0.8 & 0.1 & 0.7 & 13.1 & 87.5 \\
\hline Germany $^{3}$ & -0.4 & -0.6 & 0.2 & 11.1 & \\
\hline Greece $^{3}$ & 2.1 & 1.6 & 0.5 & 11.1 & 22.8 \\
\hline Iceland & 1.1 & 1.3 & -0.2 & 12.0 & \\
\hline Ireland $^{3}$ & 5.7 & 5.1 & 0.6 & 9.2 & 10.7 \\
\hline Italy & -0.6 & -1.1 & 0.4 & 7.5 & \\
\hline Japan & 0.9 & 0.6 & 0.3 & 11.0 & 29.3 \\
\hline Luxembourg $^{3}$ & 0.9 & 0.7 & 0.2 & 3.3 & 25.0 \\
\hline Mexico $^{2}$ & 6.2 & 2.5 & 3.7 & 54.2 & 60.1 \\
\hline Netherlands & 1.8 & 1.3 & 0.6 & 11.4 & 30.6 \\
\hline Portugal & -0.6 & -1.2 & 0.6 & 12.2 & \\
\hline Spain & 2.7 & 1.4 & 1.3 & 33.6 & 47.6 \\
\hline Sweden $^{2}$ & -1.8 & -2.6 & 0.8 & 14.6 & \\
\hline Switzerland & -0.5 & 0.2 & -0.7 & 10.9 & \\
\hline United Kingdom & 1.4 & 1.0 & 0.5 & 7.4 & 34.0 \\
\hline
\end{tabular}

Notes:

1. In most countries temporary workers are distinguished from permanent workers as being individuals with a work contract of fixed duration. The data on the numbers of temporary workers are not fully comparable across countries as specific definitions vary; for example, the data may or may not include certain groups such as those working for employment agencies, apprentices, trainees and seasonal workers. See OECD Employment Outlook, 1996 for further details on the definition of temporary work.

2. $1995-97$

3. 1993-96

Source : OECD Employment outlook, several issues.

How do these patterns of employment relate to regulations in the product and labour market? As mentioned in the previous section, empirical evidence on the labour market effects of regulations is mixed and often altogether lacking. In this section we relate the indicators of product and labour market regulations to the three main indicators of employment patterns.

Figure 9 focuses on business-sector employment rates. Agricultural employment is not considered in the figure given the large proportion of self-employed in that sector who are only marginally affected by the product and labour market regulations examined in this paper. The bottom panel suggests that a significant correlation exists between employment rate and the stance of EPL: tight regimes tending to be associated with a lower proportion of employment in the non-agricultural business sector. The relationship between product market 
regulation and business sector employment is even stronger, although the country sample is somewhat smaller than that for EPL regulations.

Figure 9. Employment rate in the non-agricultural business sector and regulations, 1995
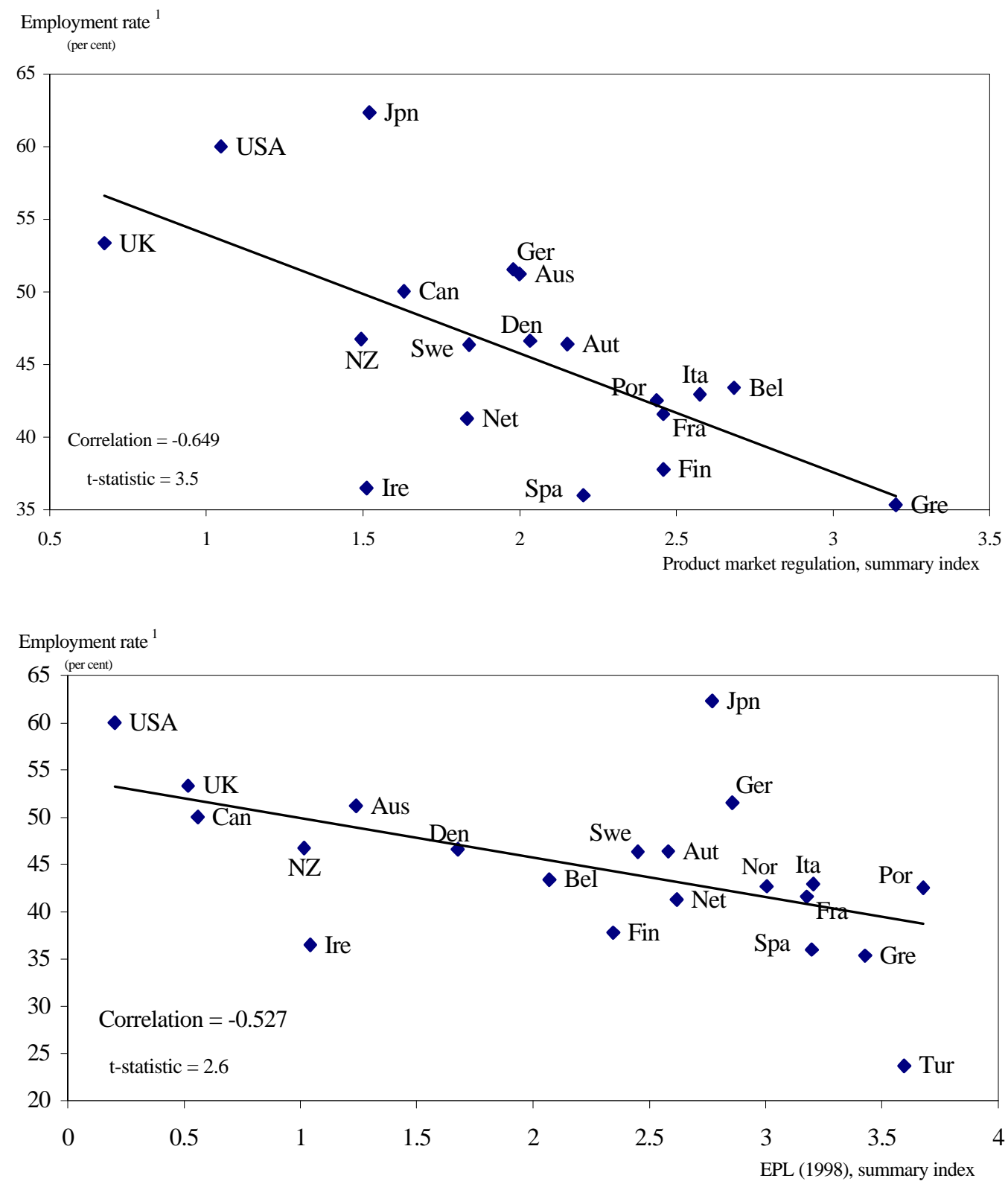

There is also a significant correlation between the share of self-employed and a measure of excess regulation for the creation of corporate firm versus the creation of sole proprietor enterprise (Figure 10): in countries where regulations for corporations are stricter than those for sole proprietor firms, there is a higher incidence of self-employed. ${ }^{23}$ The rationale for the use of a measure of excess regulation instead of a simple indicator of regulation for sole proprietorship is that ceteris paribus, within a country, the choice between

23. Belgium is a clear outlier in this figure, combining relatively more strict regulations for the creation of sole proprietor enterprises with a fairly large share of self employment in the business sector. 
the type of firm to create does not necessarily depend upon the absolute degree of stringency of regulations but rather on the relative degree of stringency vis à vis the alternative.

Figure 10. Share of self-employed and product market regulations

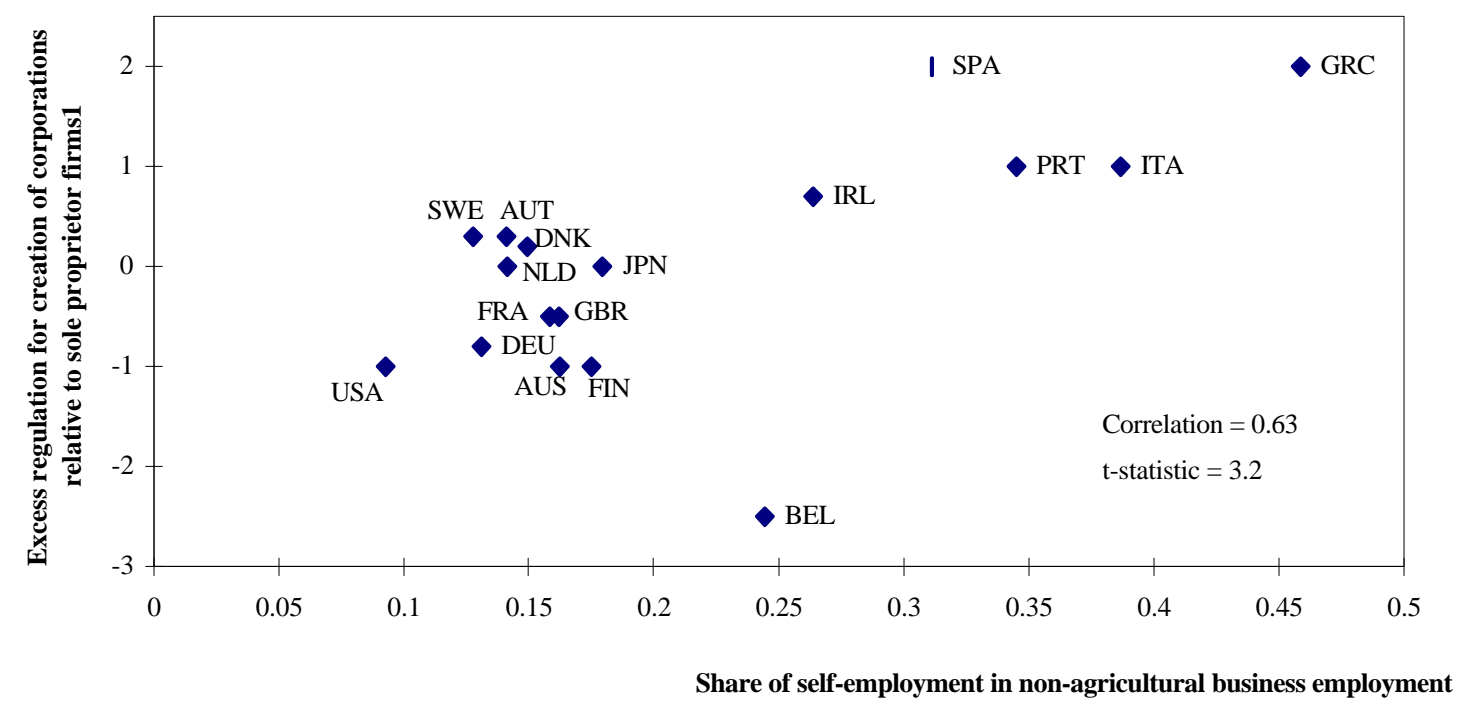

1. The difference between the indicators of administrative burdens on the creation of corporations and sole proprietor firms.

Figure 11 sheds light on the potential effects of EPL regulation on temporary employment. As in the previous case we have used a concept of excess regulation: the difference in the stringency of EPL regulations for permanent versus temporary employment. The figure gives only a partial support to the idea that stricter regulations for permanent employment relative to those for temporary employment lead to a higher share of temporary employment in the economy. There is indeed a positive association between the excess regulation and the incidence of temporary employment but it is not statistically significant. There are two clear outliers, Spain and to some extent Australia. In the latter case, we have already stressed that the interpretation of temporary employment is somewhat different that that of most European countries. In the case of Spain the excess regulation for permanent workers has had a disproportionate impact on the development of temporary employment. Spain has very tight regulations on both permanent and temporary employment and the difference in stringency between the two has de facto produced a very strong impact on employers' preference for temporary employment. This may suggest the existence of non linear effects stemming from regulations: in countries with very stringent EPL, a relative small difference in EPL between temporary and permanent employment may lead to more significant shifts towards one or the other than in countries with less restrictive overall regulatory stances. 
Figure 11 Employment protection legislation and temporary employment, 1995

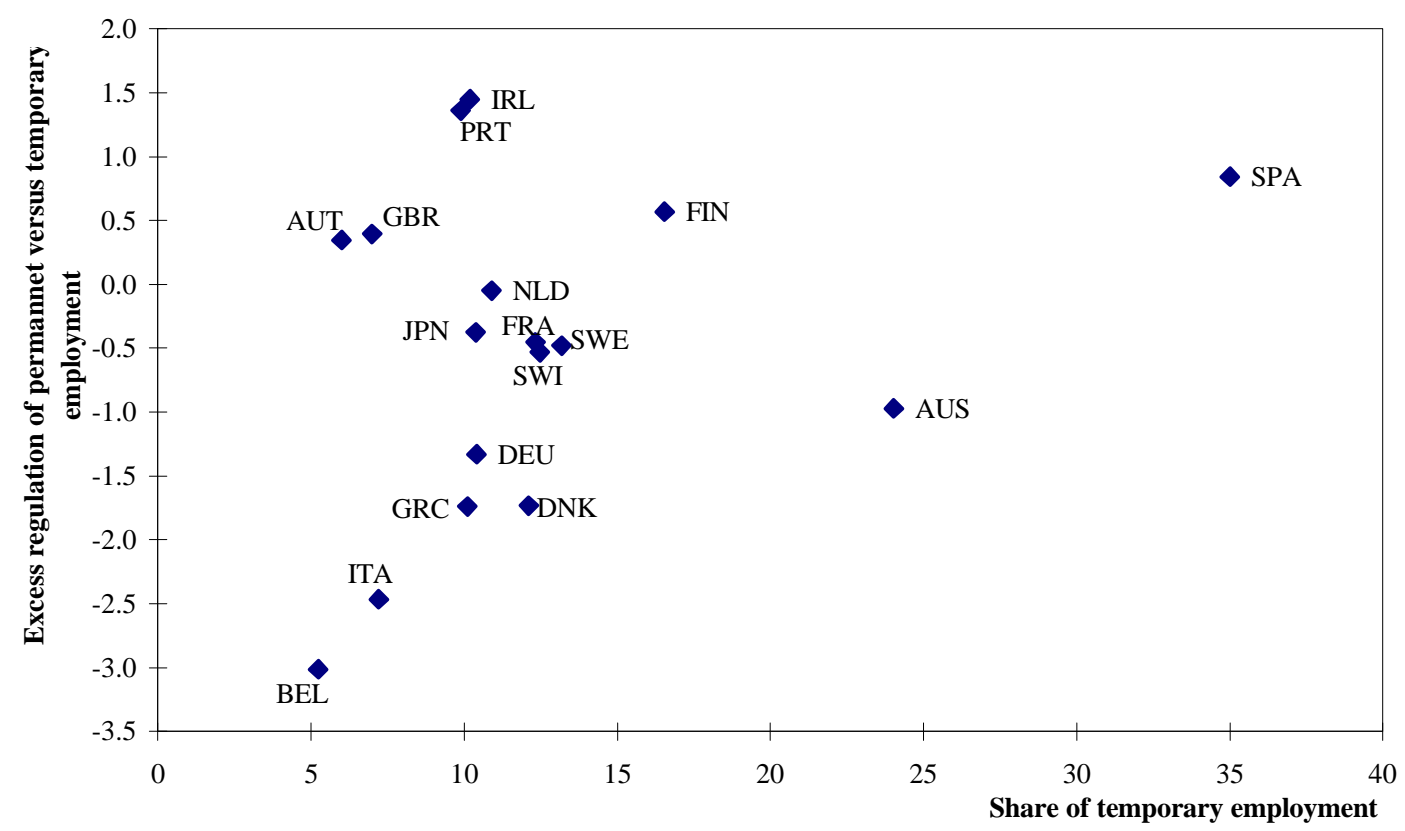

correlation $=0.28$

$\mathrm{t}-$ statistics $=1.19$

4.2 An empirical investigation of the determinants of non-agricultural employment rate

The analysis in the previous section suggests that regulations on the product and labour markets can play a significant role on the level and composition of employment. However, many other factors are likely to affect employment over and above regulations. In this section, we move away from simple bivariate correlations and estimate a structural model of employment including a number of explanatory variables in addition to EPL and product market regulations. In particular, we focus on the structural determinants of the non-agricultural business sector employment rate across countries and over time.

\subsubsection{The reduced-form model}

The theoretical framework for the analysis follows the familiar LayardNickell-Jackman (1991) bargaining model. The essential features of this model are an upward sloping wage-setting schedule, based on the assumption that real wages are the results of a bargaining process between employers and employees, who are able to exert some market power, combined with a downward sloping labour demand schedule. The labour demand schedule is influenced by product market conditions, while the wage-setting schedule is influenced by wage push factors, including labour market policies, the strength of workers in the wage bargaining process and, more generally, the institutional framework of the labour market. This simple model leads to the identification of a reduced-form employment rate equation.

A number of structural elements have been identified in the literature (for an exhaustive review see: OECD Jobs Study, 1994; Nickell and Layard, 1997) as contributing to 
the equilibrium level of employment (unemployment). Here we consider those for which data exist for a significant number of countries over time: i) an indicator of the average unemployment benefit replacement rate (average of different duration and family conditions of the unemployed person); ii) the system of wage bargaining including the union density (the proportion of workers who are member of trade unions) and the form of bargaining; iii) the level of taxes on the use of labour ${ }^{24}$; and iv) the summary indicator of EPL. ${ }^{25}$

The summary indicator of the bargaining system combines two aspects: the level of bargaining, being centralised, intermediate (at sector or regional), or decentralised (firm level); and the degree of co-ordination amongst, on the one hand, employers' associations and, on the other hand, trade unions. This combined variable allows considering cases where co-operation between employers and unions in an industry bargaining setting (e.g., Germany and Austria and, more recently, Italy, Ireland, the Netherlands with the income policy agreements) may be an alternative, or functionally equivalent, to centralised systems, thereby mimicking their outcomes.

We include the public employment rate as an additional explanatory variable in the equation to test for the hypothesis that only business sector employment rate is affected by policy institutions and labour and product market regulations. In other words, a unitary coefficient on the public employment rate would fully justify the focus on the business sector employment rate for the study of the effects of institutions and regulations on employment.

The high correlation between the summary indicator of product market regulation and that of labour market regulation makes it difficult to identify their respective contribution to employment outcomes. In addition, for the former we only have one observation (referring to 1997/98) which limits its use in a panel data estimation procedure. Thus, we opted for a two-stage approach whereby we first estimate a reduced-form equation using a panel of cross-country, time-series variables and then correlate the estimated country-specific fixed effects with the indicator of product market regulation. The country-specific effects are already purged of the effects of EPL on employment rates, and thereby the correlation with PM regulations should be considered as an additional effect of these regulations to that due to the high collinearity between the two regulatory regimes.

\subsubsection{The empirical results}

Table 4 presents the results of our reduced-form non-agricultural employment rate equation, which was estimated using a panel of 19 OECD countries over the 1982-1995

24. The tax wedge on the use of labour is the ratio of (employers' and employees') social security contributions and income taxes over total labour costs (employers' social security contributions plus gross wages). It should be stressed that the taxes on labour may have an impact on equilibrium employment only in the presence of market imperfections. For example, workers may be able to resist offsetting wage cuts in a collective bargaining framework; unemployment benefits are in some cases fixed or subject to floors and ceilings which weaken their relationship with earnings; and non-labour income effects may be important (Phelps, 1994; Pissarides, 1996).

25. The summary indicator of EPL refers to 1990 and to 1998 . The raw indicators of regulations referring to 1990 (on which the summary indicators have been constructed) are from the OECD Jobs Study (1994). The methodology used to construct the timevarying EPL indicator is described in Nicoletti and Scarpetta (1999). 
period. ${ }^{26}$ More details on the econometric results presented in the Table are in Nicoletti and Scarpetta (1999).

Table 4 Reduced-form employment rate equations, 1982-1995 (non-agricultural employment/working age population, fixed effects)

\section{Independent \\ variables}

Gov. sector employment

Unemployment benefits: repl. rate

Union density

Corporatism (intermediate)

Corporatism (high)

Employment protection legislation

Tax wedge

Output gap

\begin{tabular}{ccc} 
coeff. & st- err. & T-stat. \\
\hline $\mathbf{0 . 7 1}$ & 0.12 & 6.03 \\
$\mathbf{- 0 . 1 1}$ & 0.03 & -4.22 \\
$\mathbf{- 0 . 0 7}$ & 0.03 & -2.67 \\
$\mathbf{- 1 . 7 7}$ & 0.44 & -4.05 \\
$\mathbf{0 . 7 4}$ & 0.41 & 1.81 \\
$\mathbf{- 1 . 3 5}$ & 0.71 & -1.91 \\
$\mathbf{- 0 . 0 9}$ & 0.05 & -1.73 \\
$\mathbf{0 . 6 1}$ & 0.04 & 17.1 \\
\hline
\end{tabular}

\begin{tabular}{lc} 
No. of observations & 223 \\
No. of countries & 19 \\
\hline F-test (fixed effects) & $129.1 * * *$ \\
F-test (gov. sect. empl. $=1)^{1}$ & $6.1 * *$ \\
\hline
\end{tabular}

Each coefficient represents the expected change in the employment rate by an unitary change in the independent variable.

$* * *$ : statistically significant at the $1 \%$ level; ** at the $5 \%$ level; at the $10 \%$ level.

1. The null hypothesis is that the coefficient of the gov. sect. employment rate is equal to 1 . The test does not reject the null hypothesis at the 1 per cent level.

See Nicoletti and Scarpetta (1999) for more details.

The F-test at the bottom of Table 4 suggests that the null hypothesis of a unitary coefficient for the public employment rate is rejected at the 5 per cent level. Put in another way, there is some evidence that, over the period of time considered in the analysis, public employment crowded out private employment, but the estimated effect is rather modest. It should be stressed that this is only a partial analysis: to the extent that public employment is financed by increased tax rates-- whose coefficient is negative and statistically significant -

26. In the Table, the two variables referring to the centralisation/co-ordination of the wage bargaining indicate the effects of intermediate or high centralisation/co-ordination with respect to that of decentralised systems. The distribution of countries according to the different aspects of collective bargaining and changes over time is presented in Elmeskov, Martin and Scarpetta (1998). 
the detrimental effect of public employment on business-sector employment may become larger.

Table 4 also suggests that income support systems affect employment outcomes. In particular, higher average replacement rates and lead to lower employment rates (and higher unemployment rates, see Scarpetta, 1996). These findings corroborate the idea that the effects of overly generous benefits on the reservation wage of unemployed job-seekers may dominate the positive impact on search effectiveness through income support, thereby leading to lower equilibrium employment rates. Moreover, different collective bargaining arrangements affect labour market outcomes. The estimated coefficients for the measures of centralisation/co-ordination (decentralised countries are the reference group) give some support to the hump-shaped hypothesis (Calmfors and Driffill, 1988), whereby both highly centralised/co-ordinated systems and fully decentralised systems help to restrain the wage claims of insiders and raise employment. ${ }^{27} \quad$ It is also interesting to note that the tax wedge effect appears to be statistically significant. These results confirm recent findings by Nickell and Layard (1997) and Elmeskov et al. (1998). The Table also suggests a significant impact of stringent employment protection regulations on employment rates. This result reinforces the evidence discussed above on the basis of bivariate correlations.

\subsubsection{Explaining differences in employment to population ratios}

How do these results help to explain cross-country differences in employment to population ratios? To address this question, Table 5 breaks down the difference between each country's non-cyclical employment rate $^{28}$ and the OECD average into its determinants, namely differences in unemployment benefits, the tax wedge, employment protection regulations and the wage bargaining system. The last column in the table shows the unexplained part of the cross-country time-series variability accounting for unobserved country-specific factors $^{29}$. The parameters referring to the wage bargaining system include the combined effects of union density and the centralisation/co ordination of wage bargaining.

27. The coefficient for intermediate level of bargaining is even larger and more significant if time-varying groupings of centralisation/co-ordination are replaced by fixed groupings (late 1980s). This can be explained by the fact that moves towards higher centralisation/co-ordination occurred in the eighties, while moves towards further decentralisation occurred only in the late eighties/early nineties and, consequently, there has been less time for their beneficial effects to surface in the labour market.

28. The non-cyclical non-agricultural business sector employment rate is calculated as follows: from the estimated parameters actual non-agricultural business sector employment rate is calculated; then the effect of the cycle is defined on the basis of the coefficient on the output gap as follows: non-cyclical employment rate $=$ actual employment rate - ( $\beta$ gap $)^{*}$ gap, where $\beta$ gap is the coefficient for the gap in Table 4.

29. A positive value of the country-specific effect means that the included explanatory variables would predict a lower-than-observed employment rate, and that other missing variables are needed to explain the residual employment and vice versa. 
Table 5 Explaining cross-country differences in non-agricultural business sector employment rate

\begin{tabular}{|c|c|c|c|c|c|c|}
\hline & $\begin{array}{l}\text { difference } \\
\mathrm{er}_{\mathrm{i}}-\mathrm{er}_{\mathrm{OECD}}{ }^{\mathrm{a}} \\
\end{array}$ & UB & $\begin{array}{c}\text { Institutional } \\
\text { factors }\end{array}$ & EPL & TWEDGE & $\begin{array}{c}\text { country-specific } \\
\text { effect }^{\mathrm{c}}\end{array}$ \\
\hline \multicolumn{7}{|l|}{ country } \\
\hline Australia & 4.2 & 0.5 & -0.3 & 0.9 & 1.5 & 1.7 \\
\hline Austria & -0.7 & 0.2 & 0.6 & -0.1 & -0.1 & -1.2 \\
\hline Belgium & -4.8 & -1.4 & -2.2 & -0.4 & -1.4 & 0.5 \\
\hline Canada & 4.7 & 0.1 & 0.8 & 1.4 & 1.0 & 1.5 \\
\hline Denmark & 3.9 & -3.0 & -1.4 & 0.0 & -0.8 & 9.0 \\
\hline Finland & -0.2 & -0.6 & -3.0 & -0.1 & 0.1 & 3.3 \\
\hline France & -4.2 & -0.7 & 0.8 & -0.4 & -0.6 & -3.2 \\
\hline West Germany & 2.1 & 0.2 & 1.7 & -1.0 & -0.7 & 1.9 \\
\hline Ireland & -11.3 & 0.3 & 0.0 & 1.0 & -0.2 & -12.3 \\
\hline Italy & -6.2 & 2.7 & 1.6 & -1.2 & -1.1 & -8.2 \\
\hline Japan & 10.0 & 2.2 & 1.4 & -0.3 & 1.7 & 5.0 \\
\hline Netherlands & -7.4 & -2.3 & 2.2 & -0.6 & -0.9 & -5.7 \\
\hline New Zealand & 0.1 & -0.1 & -0.7 & 1.0 & 1.3 & -1.5 \\
\hline Norway & 2.9 & -0.9 & -0.1 & -0.6 & -0.2 & 4.7 \\
\hline Portugal & -4.7 & 0.2 & -1.4 & -1.2 & 0.5 & -2.9 \\
\hline Spain & -12.3 & -0.4 & 1.0 & -0.9 & 0.1 & -12.1 \\
\hline Sweden & 6.8 & 0.1 & -2.8 & -0.7 & -1.1 & 11.2 \\
\hline United Kingdom & 6.1 & 1.2 & -0.4 & 1.4 & 0.4 & 3.6 \\
\hline United States & 11.0 & 2.0 & 2.1 & 1.6 & 0.7 & 4.6 \\
\hline
\end{tabular}

a) Actual non-agricultural employment rate minus government employment and minus the cyclical component estimated from the coefficient of the output gap.

b) Union density (UDENS) and the degree of centralisation/co-ordination.

c) The country-specific effect is calculated as a residual.

Source: See Nicoletti and Scarpetta (1999) for more details.

The table confirms that a limited number of policy and institutional factors can explain a significant proportion of the observed differences in non-cyclical employment rates. However, in a number of cases, other omitted factors contribute to explain their employment rates over and above those that we could include in our model (as shown by the relatively large country-specific factors). The table suggests that overly generous unemployment benefits could account for as much $2 / 3$ percentage points lower non-agricultural business sector employment rates in some countries. Likewise, a wage bargaining characterised by unco-ordinated sectoral agreements may lead 3 percentage points lower employment rates (at the maximum). Likewise, excessive taxes on labour use in Belgium, Italy and Sweden could be considered responsible for more than 1 percentage point lower employment rates. Turning to EPL, the table suggests that these regulations significantly affect employment rates, other things being equal. While countries with relatively lax systems (Canada, the United Kingdom and the United States) enjoy higher employment rates (around 1.5 percentage points), those with very strict systems (e.g. Portugal and Italy) may have 1.2 percentage points lower employment rates.

\subsubsection{The role of product market regulations}

As stressed above, the index of regulations on the product market cannot be included in the regression analysis due to the lack of time dimension and, more importantly, because of the high correlation with the index of employment protection regulations. However, the bivariate correlation between the unexplained country-specific effects (Table 5) and the PM index may shed some light on the role of strict regulations in the product market over and above those stemming from the combined effect with labour market regulations Table 6. As expected, the significant correlations found in the previous bivariate analysis are 
weakened once controlling for several factors affecting cross-country differences in employment. However, correlations generally remain correctly signed and a few of them retain significance, especially when outliers are eliminated (second column of Table 6). As mentioned above, due to lags in the effects of structural policies on market outcomes, in countries (such as Ireland) where radical product market reforms have been implemented towards the end of the sample period, the end-of-period measure of regulation necessarily bears little relationship with the average employment rate even if a strong causal link between regulations and employment were to exist. Therefore, bivariate correlations have been computed both with and without this country.

Despite the fact that there is only a weak correlation between the overall indicator of product market regulation and the country specific effects, several aspects of PM regulations seem to be more closely related with it. For example, the presence of a high degree of state control in business sector activities seem to exert a strong negative effect on business sector employment rates, especially through regulations interfering in the activity of private (or privatised) business enterprises and administrative burdens on business start-ups. In particular, entry restrictions due to costly and opaque administrative practices and the distortion of market mechanisms associated with the excessive presence of the state in the business sector would appear to explain the pattern of employment rates across OECD countries over and above the policy, regulatory and institutional factors specific to the labour market. While considering these results we should, however, keep in mind the strong positive correlation between the summary measures of EPL and product market regulation, which makes it difficult to identify their separate contribution to the explanation of cross-country differences in employment rates.

Table 6 The employment rate: country-specific effects and regulation (nonagricultural, 1982-1995)

\begin{tabular}{l|c|c}
\hline \multicolumn{1}{c|}{ Regulatory indicators } & Including outliers & Excluding outliers \\
\hline Product market regulation & & -0.30 \\
Inward-oriented policies & -0.16 & -0.40 \\
Outward-oriented policies & -0.30 & 0.31 \\
State control & 0.38 & $-0.42^{*}$ \\
Public ownership & -0.32 & -0.24 \\
Interference in private firms & -0.21 & $-0.49^{*}$ \\
Size of public enterprise sector & -0.34 & 0.01 \\
Scope of public enterprise sector & 0.05 & -0.39 \\
Special voting rights & -0.33 & $-0.67^{*}$ \\
Use of command and control regulation & $-0.60^{*}$ & -0.33 \\
Barriers to entrepreneurship & -0.17 & -0.08 \\
Administrative transparency & -0.02 & 0.28 \\
Adm. burdens on business startups & 0.24 & $-0.53^{*}$ \\
Legal barriers to entry & -0.36 & 0.35 \\
Adm. burdens for corporations & 0.26 & $-0.72^{*}$ \\
Adm. burdens for sole proprietor firms & $-0.54^{*}$ & -0.42 \\
Barriers to trade and investment & -0.17 & 0.31 \\
Regulatory and tariff barriers & 0.38 & 0.28 \\
Other trade barriers & 0.31 & 0.14 \\
Regulatory barriers & 0.22 & 0.04 \\
Non-tariff barriers & 0.10 & -0.08 \\
\hline Notes:* indicates significance at 10 per cent levels. Outlier country is Ireland & -0.12 & \\
\hline
\end{tabular}




\section{The Changing Profile of Regulations}

The above analysis suggests that the stance of product and labour markets regulations is highly correlated across countries. Moreover, both the overall regulatory environment and some institutional features of labour markets, notably the presence of overly generous unemployment benefits, sectoral and un-coordinated wage bargaining institutions, strict employment protection and high labour taxation, negatively affect employment rates, that is the capacity of economies to mobilise labour supply. However, our findings should be qualified in several ways.

First, our results rely on measures that, albeit significantly improved from previous studies, are still an approximation of actual regulatory policies, especially since it is difficult to gather information on the actual enforcement of the various regulations. Data constraints also prevent us from estimating the structural relationships and unfortunately economic theory provides little guidance in imposing those restrictions which would allow recovering from reduced form estimates the underlying structural parameters, which could be better interpreted and used in the context of policy simulation exercises.

Second, and perhaps more importantly, our findings provide only partial indications as to which institutional features would need to be reformed in order to increase employment rates. This is because the various parameter estimates summarise the impact of ceteris paribus changes in some institutional features, while the analysis in Sections 2 and 3 pointed to potentially significant interactions and complementarity among the various institutions.

Moreover, the results presented in Section 4 refer to the effects of policy and institutions in the 1982-95 period. It is difficult to extrapolate from these results the effect of policy reforms in the future insofar as reforms in one area may be nullified by contrary reforms in other areas. Put another way, reducing unemployment benefit generosity by 10 percentage points may not lead to an increase of 1.1 percentage point in the employment rate, as suggested in the previous section (Table 4), if this reduction is obtained at the cost of stricter employment protection legislation. ${ }^{30}$ The existence of this and other trade-offs (partly, but not only, dictated by political economy factors) in the design of labour market and social welfare institutions suggests that piecemeal reforms may be offset by countervailing changes in other institutional features.

Third, there are important dynamic effects of changes in institutions that are not captured by our estimates. Once more data limitations, namely the short and discontinue time-series on labour market institutions, do not allow us to estimate a richer set of parameters capturing partial adjustment to long-run equilibria. However, we have all the reasons to suspect that the adjustments to institutional changes takes time, and that reforms themselves are a long-term process. Some evidence on the sluggishness of institutional adjustment is provided below.

The slow adjustment of institutions suggests that the impact of reforms is crucially dependent on the expectations that agents have on the ultimate purpose of regulatory changes, hence on the longer-term design of institutions. These dynamic and expectational effects of reforms are likely to be very important. If reforms are perceived as temporary, it is highly

30. Buti, Sestito and Pench (1998) nicely characterise the presence of an inverse relationship between, on the one hand, "on-the-job protection", that is, various kind of obstacles to dismissals, and, on the other hand, "in-the-market" workers' protection, that is, nonemployment benefits. 
unlikely that they would work in the direction (and magnitude) implied by our parameter estimates.

Thus, the best way to interpret our findings is as indications of the fact that some regulatory and institutional environments are more conducive to low employment rates than others. Rather than using these estimates to advocate some reforms and predict their impact, we prefer to adopt here a more cautious (and positive) approach. First, we will try to identify which changes are occurring in policies, regulations and institutions across countries. The focus will be mainly on policies, regulations and institutions concerning the European labour markets. Next, based on our previous employment estimates, we will try to assess whether the observed pattern of changes is likely to lead to higher or lower employment rates. Finally, we will try to verify whether different regulatory regimes (over time and across countries) are associated to different attitudes towards social and welfare policies.

\subsection{The Institutions, They are a 'Changing}

The first question to ask is whether institutions are changing at all. According to popular wisdom, institutions, notably social welfare institutions, are something static, unmodifiable and indeed unmodified over long periods of time. Is this true?

We collected information enabling us to assess two dimensions of institutional dynamism. The first is the degree of persistence of those institutional features for which reliable measures can be obtained for sufficiently long periods of time. The second is the number and nature of reforms that have occurred in this area, as can be grasped by qualitative information on economic and policy developments in the various countries.

\subsubsection{Persistence of Institutional Features}

Table 7 displays Spearman rank-correlation as well as simple correlation coefficients of various measures of the stance of social policy and employment protection in OECD countries over time. A simple correlation coefficient close to unity for an institutional feature points to a high degree of persistence of this feature while a rank correlation coefficient approaching zero is an indication of a low persistence in the ranking. Both correlation coefficients are displayed as rank correlations can be more reliable than simple correlations when available measures are deemed to provide mainly an ordering of countries.

\section{Table 7 Persistence of Institutions (1980-1990 Correlation Coefficients)}

\begin{tabular}{|c|c|c|c|c|c|}
\hline & $\begin{array}{l}\text { Unemployment } \\
\text { Benefits }\end{array}$ & $\begin{array}{l}\text { Employment Protection } \\
\text { Legislation }\end{array}$ & Public pensions & \multicolumn{2}{|c|}{$\begin{array}{c}\text { Social } \\
\text { Assistance }\end{array}$} \\
\hline $\begin{array}{l}\text { Simple } \\
\text { Correlation }\end{array}$ & $0.94 * *$ & $0.93 * *$ & 0.98 & $* *$ & $0.58 *$ \\
\hline $\begin{array}{l}\text { Spearman Rank } \\
\text { Correlation }\end{array}$ & $0.93 * *$ & $0.90 * *$ & 0.98 & $* *$ & $0.75 *$ \\
\hline $\begin{array}{l}\text { Number } \\
\text { observations }\end{array}$ of & 19 & 14 & & 13 & 14 \\
\hline
\end{tabular}

Note: Two asterisks denote significance at 99\% confidence level, an asterisk at $95 \%$ confidence level 
The first measure captures the generosity of unemployment benefits. In Table 7, we have used a summary measure of generosity that focuses on the first two years of unemployment (in any event, in most countries individuals with unemployment durations longer than 24 months are eligible only to means-tested social assistance, whose coverage and level is assessed below). Second, we have weighted replacement rates for the second year of unemployment by the incidence of long-term unemployment. ${ }^{31}$ This means that, in a country where 50 per cent of unemployment is long-term (lasts more than 12 months), a weight of 0.5 is given to replacement rates offered in the second year of joblessness. ${ }^{32}$ The correlation coefficients point to a relatively high degree of persistence in the way in which countries differ in the provision of income support to the unemployed individuals.

The second measure considered in Table 7 deals with employment protection regulations. As discussed in Section 2, also in this case there is indication of a high persistence in the relative position of the various countries as far as employment protection is concerned. The third institutional feature is a measure of the generosity of public pensions, namely the ratio between the (public) pensions received by persons aged 65-74 and the disposable income of individuals aged 55 to 64 . This is a summary measure of the actual contribution offered by public pensions to the replacement of pre-retirement earnings. Pensions are relevant also in this context because of the role played by early retirement schemes as non-employment benefits. Data come from national sources, which have been assembled (in a way to satisfy cross-country comparability purposes) by OECD. This seemes to be the most persistent institutional feature of the four: both correlation coefficients are indeed close to unity.

The fourth measure captures social assistance provision, namely those cash transfer schemes aimed at guaranteeing subsistence to people in need. The generosity measures are in this case provided by the ratio of social assistance expenditure ${ }^{33}$ to the number of persons having income lower or equal than fifty per cent of the average wage. We have in this case a rather low persistence in the levels of social assistance, and some indication that rank reversals have occurred in the generosity and coverage of income support schemes of the last resort.

Overall, institutional asymmetries across countries would seem to be highly persistent and evolutions in the '90s not to have significantly affected the country rankings which were prevailing in the mid " $80 \mathrm{~s}$. The only exception is social assistance where there is evidence of rank reversals and more broadly significant changes in the levels and coverage of provisions.

31. These replacement rates are from the OECD database. The overall summary measure of the generosity of unemployment benefits done by the OECD is based on simple averages of nominal replacement rates over the first five years of unemployment. However, the replacement rates offered in the first year of joblessness may be more important than, say, the benefits provided in the fifth year. Likewise, it may be important to consider actual coverage of benefits.

32. We are aware of the fact that the duration of unemployment may be affected by the duration of benefits. Yet, this "endogeneity" problem of our measure seems to us to pose less serious problems than giving the same weight to all years of unemployment.

33. Social assistance expenditure is measured according to the OECD Social Expenditure Database. 


\subsubsection{Taking Stock of Institutional Reforms}

Table 8 summarises the number and marginal or radical nature of reforms carried out in the EU over the 1985-95 period in three domains: employment protection, unemployment benefits and pensions. Information as to the broad direction of reforms (more or less employment security, more or less generous non-employment benefit systems, more or less encompassing public pensions) is also provided. A variety of sources (including country economic reviews carried out by the OECD, Income Data Source studies, EC-MISSOC reports, etc.) was used to take stock of reforms carried out in Europe.

The inventory of reforms is organised along two main dimensions. On the one hand, we distinguish reforms on the basis of their broad orientation, that is, whether they tend to reduce or increase the generosity of public pensions and non-employment benefits and make employment protection more or less strict. This is, after all, the same dimension along which the figures commented so far were organised and therefore we believe that it is not necessary to add more information here.

On the other hand, we distinguish reforms depending on whether they are marginal or radical. This procedure is done in two stages. At first, we rely on qualitative assessment, which are based on an evaluation of the scope of the various reforms. In particular, we preliminarily classify as radical those reforms that satisfy at least one of the following criteria: reduce replacement rates by at least 10 per cent, are comprehensive, that is, do not address just minor features of the cash transfer schemes but rather reform their broader design, and involve existing entitlements rather than being simply phased-in for the new beneficiaries of the various schemes (e.g., reforms of employment protection should concern also workers under permanent contracts). In the second stage we look at the actual behaviour of the series which should be most affected by the reforms and only if we observe a change in the underlying trend of these series we confirm our qualitative assessment. Clearly the secondstage of the procedure can only be implemented for the reforms carried out before 1993 as we need a minimum number of in order observations to establish whether a change in the underlying trend has occurred. Sometimes even in the case of reforms done before 1993 the second-stage validation procedure cannot be implemented as some reforms are followed just a few years after by regulatory changes moving in the opposite direction and therefore undoing part of the initial institutional changes. In all the cases where the second stage procedure cannot be implemented, only the first stage assessment is used. The first stage assessment was validated in 85 per cent of the cases. 
Table 8. Reforms of Employment Protection Legislation (EPL), Non-Employment Benefits and Pension Systems in Europe (19861997)

\begin{tabular}{ll|c|c|c} 
& \multicolumn{2}{c}{$\begin{array}{c}\text { Decreasing Generosity and } \\
\text { Regulations }\end{array}$} & $\begin{array}{c}\text { Increasing Generosity and } \\
\text { Regulations }\end{array}$ & 16 \\
Employment & Marginal & 20 & 2 & $\mathbf{3 6}$ \\
Protection Legislation & & 6 & 32 & $\mathbf{8}$ \\
\hline Non-Employment & Madical & 37 & 2 & $\mathbf{6 9}$ \\
Benefits & Radical & 7 & 37 & $\mathbf{9}$ \\
\hline Public Pensions & Marginal & 30 & 2 & $\mathbf{6 7}$ \\
& Radical & 7 & $\mathbf{9 1}$ & $\mathbf{9}$ \\
\hline Total per columns & & $\mathbf{1 0 7}$ & & $\mathbf{1 9 8}$ \\
\hline Source Fondazine
\end{tabular}

Source: Fondazione RODOLFO DEBENEDETTI

Note: See the text for details on how reforms are classified (e.g., the distinction between marginal and radical reforms). 
Which series are we using in the empirical validation procedures? In the case of employment protection we look at labour market flows, notably unemployment inflows, as previous work has found a strong negative correlation between employment protection and the incidence of unemployment. ${ }^{34}$ In the case of pension reforms, we look at the dynamics of pension expenditures and revenues earmarked to the public pension funds: we expect radical reforms to significantly affect at least one of the two. Finally, in the case of non-employment benefits, we use proxy outflows from unemployment ${ }^{35}$ (or outflows from the live registers to jobs in the countries for which such data are available): we expect radical reforms to significantly affect exit flows from unemployment (unfortunately we have no data on exit flows from nonemployment).

The most striking fact highlighted by the table is the large number of reforms: one can count 198 reforms, more than one every two years for each institutional feature. Significantly, reforms often seem to move in opposite directions. For instance there is almost the same number of reforms increasing the generosity of public pension (39) than those reducing it (37) and often such mutually offsetting changes occur within the same country at a short distance. Moreover, reforms are, for the most, of the incremental and marginal type, which means that they often did not remove old regulations, but simply added new ones. As stressed above, in the field of employment protection, for instance, many reforms were confined to the introduction of new types of contracts leaving the "regular" ones untouched. Similarly, cuts to nonemployment benefits were rarely discrete, as they involved reductions, at most, of 5-10 per cent of replacement rates.

Albeit reforms were mainly marginal and often inconsistent, there is little doubt that institutions were and are changing. The obvious question to follow is: in which direction did these changes occur?

\subsection{Reform patterns and employment outcomes}

There is not a common pattern of reforms that can be discerned across countries as, after all, initial conditions were significantly different from country to country. Yet, some characteristics of reforms are shared across quite a wide range of countries.

The dominant tendency in the field of unemployment benefit systems and, more broadly, measures dealing with redundancies, has been towards a tightening of the systems, in terms of stricter eligibility criteria, shorter maximum duration of benefits, and, in some cases, lower replacement rates. This is the route taken by countries like Austria, Canada, Iceland, Ireland, the Netherlands, Norway, Spain and the UK. However, in some of the countries were these programmes were initially undersized by OECD standards - e.g., Southern European countries like Greece and Italy - the tendency has been instead towards the introduction of new schemes (e.g., the so-called "Liste di Mobilità" in Italy) which provide a larger replacement of earnings in the case of job loss. Access to early retirement schemes, invalidity or sick benefits has been restricted in those countries, such as Austria, Italy, Germany, the Netherlands, Norway and Spain, which had in the past made a large use of these (rather expensive) schemes to cushion the social costs of redundancies.

As already stressed in Section 1, reforms of employment protection schemes have generally involved the liberalisation of fixed-term contracts and the introduction of a wider range of non-standards

34. See, for instance, Boeri, 1999.

35. Proxy outflow rates are computed as follows $O_{t, t+1}=I_{t, t+1}-\left(U_{t+1}-U_{t}\right)$ where $\mathrm{O}$ denotes proxy outflows, I inflows and U unemployment levels. All primary data come from the OECD Unemployment Duration database. 
forms of employment (e.g., temporary agency work). This dominant trend is towards increasing flexibility in the adjustment of employment has been coupled with reforms aimed at more flexible working time arrangements in a number of countries. There are, however, a few exceptions as in France where EPL for permanent workers has been tightened and law the normal working week to 35 hours has been adopted.

Industrial relations have generally evolved by assigning greater importance to decentralised wage bargaining institutions or better co-ordination amongst social partners at the different levels of negotiation (national, sectoral, firm) (see OECD, 1999b). The most radical reforms in this context occurred in New Zealand, Australia and the UK. In Continental Europe reforms have been more gradual and have typically resulted in the establishment of two-tier bargaining structures where nation-wide or sectoral wage agreements are supplemented by firm-level collective bargaining structures. The scope for exemptions from contractual minima set in the context of national agreements has also been expanded in countries like Germany and Italy, mainly as a recognition of the fact that these floors were crowding-out employment in the new Länders or in the Mezzogiorno. In the midst of reforms, co-ordination of de-centralised wage agreements is difficult and was indeed hardly achieved. Most frequently, the adding of a second bargaining tier resulted into "summatory" effects, thereby wage increases agreed at the firm-level were simply adding to those reached at the national or sectoral level.

There are also indications that some easing of product market regulations occurred in a number of countries (see OECD, 1999b). In particular, licensing requirements were simplified in the Netherlands, more competition in professional services (e.g., lawyers) was granted in Germany, Finland, Spain and Switzerland, while shop-opening hours were de-restricted in Austria, Belgium, Denmark, Finland, Germany, Greece and Italy. EU-wide liberalisation is taking place in telecommunications, airlines and, much more slowly, in the electricity industry, and steps towards allowing for more competition in financial services have been taken or are envisaged in a wide range of countries. However, as shown in Section 2, even at the EU level cross-country differences in product market regulations remain significant, especially in the areas of state control and barriers to entrepreneurship.

Overall, these reforms are for the most oriented towards directions which - according to the results of the multivariate analysis in Section 2 - should enhance employment rates. However, a number of conditions will have to be met before the reforms fully display their effects. First, as most reforms are marginal and our parameter estimates point to rather small effects of the various institutional features on employment to population ratios, reforms should gain in scope in order to have some sizeable impact on the labour market. Second, given the role played by expectations and the fact that reversals of liberalisation episodes have occurred in some countries, reforms will have to gain momentum in order to be credible and we believe that they need to be credible in order to be effective. Thirdly, reforms will have to be encompassing rather than piecemeal, thereby avoiding that substitutions of policy instruments occur which jeopardise the ultimate purpose of reforms.

In a nutshell, predictions as to the likely impact of ongoing reforms can only be made based on some understanding of what lies behind these reform efforts. Are they just episodes, and governments are bound, sooner or later, to be punished by voters for their bravery? Are the policy changes simply devices to comply with recommendations of international organisations exerting structural surveillance and imposing their conditionality (if any) on economic policies? Or are these reforms the by-product of a long-term process, e.g. result from stricter regional integration and capital mobility putting competitive pressure on national welfare systems and domestic regulations obstructing business? These questions are particularly relevant to understand the likely evolution of institutional reforms in the EMU area. 


\subsection{Regulatory reform, economic integration and the convergence/divergence of social policies}

Product market liberalisation has been implemented in Europe mainly within the framework of the EU Directives, which provide precise guidelines for countries (including administrative and judicial ways to impose compliance). By contrast, reforms in the labour market have been more disparate and not necessarily coherent across countries, since they remain largely within the domain of national policies. However, the EMU may impress a change in the labour market reform effort of the member countries.

There are, at least, two schools of thought on the effects of EMU on structural reforms. For illustrative purposes it is useful to characterise these schools by taking their most extreme positions. We are fully aware that there are many other speculations on the forefront, which offer a much more balanced view than those proposed below.

On the one hand, there are those arguing that EMU will force governments to necessarily deal with structural issues, as there is hardly anything else to do. According to the so-called "there-is-noalternative" or TINA argument -- as labelled by Calmfors (1998), Governments in the monetary union will have to concentrate their efforts on structural policies. With monetary policy decided elsewhere and tight conditions for fiscal policy within the framework of the Stability and Growth Pact, countries will be able to cope with (asymmetric) shocks only if they increase the flexibility of their product and labour markets. Other scholars argue that the removal of remaining barriers to the mobility of goods and services and the greater price transparency involved by the adoption of a common currency (in the context of the EMU) will increase competitive pressures on national fiscal systems. This will create stronger and stronger pressures towards the dismantling of the welfare state (Sinn, 1998), set in motion a race-to-the-bottom in social welfare provision and possibly phase-out employment protection in an attempt to attract FDIs. Depending on whether this tendency towards more structural reforms and smaller social welfare systems is deemed desirable or not, arguments are made for a harmonisation of social and labour policies at the EU level or simply their co-ordination.

On the other hand, there are those arguing that EMU will hardly make any difference in terms of institutional reforms, except those that are intrinsic to the creation of a monetary union. For instance, there is little doubt that the monetary union will de facto de-centralise even the most centralised national wage bargaining systems. Besides these initial effects of EMU on institutions, the monetary union will play in favour of the status quo for a number of reasons. First, it is suggested that incentives to reform labour markets in order to cope with the inflation bias associated with structural unemployment will be reduced under the EMU because, with the ECB determining monetary policy in the whole currency union, labour market reforms in a given country will have only a small effect on the common rate of inflation. Second, in the light of the heterogeneity of institutions across countries (and of the substitutability and complementarity of those), the way in which competitive pressures will act to reduce social welfare provisions is not at all self-evident. Put another way, there are many arbitrage conditions to be met and just one factor, namely capital, moving around. It should be stressed that the findings of the analysis above on the incremental and marginal nature of reforms ultimately suggest that the complexity of social welfare and labour institutions is almost everywhere increasing rather than decreasing over time. This supports the case for a lack of transparency and persistent country-specific institutional design.

If theorists are divided as to the likely impact of EMU on institutional reforms, empiricism offers only modest guidance to clarify these issues. Lucas' critique implies that making inferences on future trends based on past observations may be highly misleading when structural breaks, like the advent of EMU, occur. Yet, this should not sound as a justification to avoid spending time looking at data available on the convergence and divergence of institutions in the last fifteen years. At worse, this exercise will tell us something about the effects of economic integration in broad terms rather than on the effects of EMU. 
Table 9 provides information on social spending over GDP by main expenditure item. In addition to looking at convergence within the OECD area, we also look at convergence within the EU as well as the three country clusters (Southern Europe, Continental Europe, Common-law countries) discussed in Section 2. The latter were obtained while tracking similarities in regulatory frameworks. Yet, they are also associated with characteristics of welfare states. For instance, the strong employment protection provided in Southern European countries was historically associated with the provision of low insurance against the risk of job loss, and relatively small welfare states.

In the table, we draw on data from the OECD Social Expenditure Database and build groups of expenditure items. ${ }^{36}$ In particular, we put together old-age, survivor pensions and care for the elderly services, we include in the same group health, occupational injury and sickness benefits and we put early retirements and active policies in the broader class of measures for the unemployed. While some of these groupings may be challenged on the grounds that they mix rather different policy instruments, they are nonetheless essential to assess convergence in terms of the categories of beneficiaries of social spending. We are interested in verifying the convergence in social welfare institutions. Therefore, we tabulate not only the (un-weighted) averages, but also the (un-weighted) standard deviations of expenditure shares over GDP across and within country groups. These measures of dispersion can be used to broadly assess the degree of "sigma convergence" within and across the various country groups.

The first fact highlighted by the table is that there does not seem to be a tendency towards decreased social spending in any of the four groups of countries. If anything, expenditure increases as a share of GDP. This is important as it suggests that regulatory reform, economic integration and freer mobility of capital so far does not seem to have involved a race-to-the-bottom in welfare provision. Neither there are indications of a tendency towards convergence in the size and composition of social spending across countries. Surprisingly, diverging levels of social spending and social expenditure structures emerge within the EU: the standard deviations are almost always increasing (and this holds even accounting for scale effects, that is, using coefficients of variation rather than standard deviations). Some convergence would seem to occur within some regional blocks, notably the Southern Europe group, but this holds only in terms of overall social spending rather than for each expenditure item.

36. Eurostat has recently revised classifications of social spending in the context of the ESSPROS (European System of Integrated Social Protection Statistics) exercise, but there are as yet no series available to study convergence along those spending categories. 
Table 9 Convergence in Social Policy Expenditure (as \% of GDP)

\begin{tabular}{|c|c|c|c|c|c|c|c|c|c|c|c|c|}
\hline \multirow{2}{*}{ Unwelghted Averag } & \multicolumn{2}{|c|}{ Total 1985} & 1995 & 1980 & Old age & 1995 & \multicolumn{3}{|c|}{ Disability } & \multicolumn{3}{|c|}{ Health } \\
\hline & & & & & & & & & & & & \\
\hline Group A & 17.17 & 20.01 & 22.30 & 6.67 & 7.48 & 8.52 & 1.08 & 1.24 & 1.27 & 6.60 & 6.35 & 6.88 \\
\hline Group B & 21.13 & 22.67 & 26.38 & 7.96 & 8.16 & 9.25 & 1.90 & 1.92 & 2.15 & 6.82 & 6.83 & 7.37 \\
\hline Group C & 15.79 & 18.18 & 18.94 & 5.79 & 6.18 & 5.85 & 0.59 & 0.68 & 1.12 & 6.00 & 6.02 & 6.70 \\
\hline European Union & 21.09 & 23.29 & 24.45 & 8.30 & 9.03 & 9.41 & 1.69 & 1.84 & 1.86 & 6.94 & 6.71 & 6.64 \\
\hline \multicolumn{13}{|c|}{ Unweighted standard deviations } \\
\hline between countries & 6.67 & 6.69 & 8.12 & 2.62 & 2.72 & 3.47 & 1.02 & 0.99 & 1.05 & 2.20 & 1.90 & 2.02 \\
\hline within group A & 5.04 & 6.45 & 4.99 & 2.73 & 3.25 & 2.88 & 0.28 & 0.31 & 0.31 & 1.29 & 1.60 & 1.46 \\
\hline within group $B$ & 5.78 & 5.29 & 5.16 & 2.38 & 2.38 & 2.56 & 1.18 & 1.11 & 1.10 & 1.52 & 0.99 & 1.19 \\
\hline within group $\mathrm{C}$ & 2.40 & 3.92 & 2.43 & 1.71 & 1.56 & 1.45 & 0.21 & 0.31 & 0.86 & 1.80 & 1.33 & 0.58 \\
\hline between groups & 2.77 & 2.26 & 3.72 & 1.09 & 1.01 & 1.79 & 0.66 & 0.62 & 0.55 & 0.43 & 0.41 & 0.35 \\
\hline \multirow[t]{3}{*}{ within EU } & 5.78 & 5.03 & 8.14 & 2.17 & 2.06 & 3.56 & 1.05 & 0.94 & 1.06 & 2.08 & 1.78 & 2.16 \\
\hline & \multicolumn{3}{|c|}{ Family } & \multicolumn{3}{|c|}{ Unemployment } & \multicolumn{3}{|c|}{ House and Soc. Ass. } & \multicolumn{3}{|c|}{ Other } \\
\hline & 1980 & 1985 & 1995 & 1980 & 1985 & 1995 & 1980 & 1985 & 1995 & 1980 & 1985 & 1995 \\
\hline \multicolumn{13}{|c|}{ Unweighted Averages } \\
\hline Group A & 1.25 & 1.34 & 1.42 & 1.22 & 3.07 & 3.48 & 0.35 & 0.51 & 0.70 & 0.01 & 0.01 & 0.04 \\
\hline Group B & 2.23 & 2.12 & 2.63 & 1.73 & 2.95 & 3.97 & 0.45 & 0.62 & 0.82 & 0.04 & 0.07 & 0.12 \\
\hline Group C & 1.41 & 1.48 & 1.53 & 1.10 & 2.52 & 2.17 & 0.89 & 1.30 & 1.50 & 0.01 & 0.01 & 0.03 \\
\hline European Union & 2.07 & 2.00 & 2.11 & 1.62 & 3.01 & 3.49 & 0.44 & 0.67 & 0.79 & 0.03 & 0.03 & 0.07 \\
\hline \multicolumn{13}{|c|}{ Unweighted standard deviations } \\
\hline between countries & 1.04 & 1.04 & 1.29 & 1.21 & 1.72 & 2.02 & 0.48 & 0.66 & 0.81 & 0.08 & 0.09 & 0.13 \\
\hline within group A & 0.89 & 1.10 & 1.02 & 0.94 & 1.37 & 0.93 & 0.21 & 0.34 & 0.67 & 0.02 & 0.02 & 0.02 \\
\hline within group B & 0.84 & 0.67 & 1.13 & 1.65 & 1.81 & 1.96 & 0.30 & 0.44 & 0.57 & 0.09 & 0.11 & 0.17 \\
\hline within group C & 0.73 & 0.81 & 0.78 & 0.47 & 1.93 & 1.79 & 0.66 & 0.95 & 1.01 & 0.01 & 0.02 & 0.06 \\
\hline between groups & 0.53 & 0.42 & 0.67 & 0.33 & 0.29 & 0.93 & 0.29 & 0.43 & 0.43 & 0.02 & 0.03 & 0.05 \\
\hline within EU & 1.09 & 1.10 & 1.31 & 1.33 & 1.67 & 2.08 & 0.40 & 0.63 & 0.75 & 0.07 & 0.09 & 0.14 \\
\hline
\end{tabular}

Note:

Group A (Southern Europe): France, Italy, Portugal, Spain

Group B (Continental Europe): Australia, Austria, Denmark, Finland, Germany, Belgium, Netherlands, Norway, Switzerland

Group C (Common-law countries): United States, United Kingdom, Canada, Ireland, New Zeland

Data on social expenditure are deeply affected by differences in the efficiency of social welfare administrations and cannot capture qualitative institutional differences across countries. Thus, we looked at convergence also in terms of characteristics of the various institutions. In particular Table 10 looks at unemployment benefit systems, while Table 11 at collective bargaining institutions. The former are described in terms of generosity (replacement rates) and coverage, while the second in terms of degree of unionisation, centralisation and co-ordination. All these terms and measures should by now be familiar to the reader as they have been discussed in Sections 1 and 2.

The tables support some of the observations made above about the direction of reforms. In particular, there seems to be some tendency towards a decline in the generosity of unemployment benefit systems (replacement rates, if not necessarily coverage, decline in most country groups ${ }^{37}$ ) and in the degree of unionisation of the workforce. However, on the whole, there seems to be little support for the idea that a process of institutional convergence is at work. The overall and between groups standard deviations are increasing. Only within specific groups (e.g., the Southern European cluster) some tendency towards convergence would seem to emerge.

37. We have deliberately excluded Italy from table 10 as replacement rates computed after the introduction of the Mobility Lists are not comparable to those available before 1992, which covered only "ordinary" unemployment benefits. 
Table 10

Convergence in Unemployment Benefit Systems

\begin{tabular}{lrrrr} 
& \multicolumn{3}{c}{ UB generosity } & UB coverage \\
Country & 1991 & 1995 & 1990 & 1995 \\
\hline Austria & 31,0 & 25,8 & 89 & 90 \\
Belgium & 42,3 & 41,6 & 89 & 94 \\
Denmark & 51,9 & 70,3 & 100 & 100 \\
Finland & 38,8 & 43,2 & 101 & 100 \\
France & 37,2 & 37,5 & 81 & 77 \\
Germany & 28,1 & 26,4 & 64 & 76 \\
Greece & 17,1 & 22,1 & 53 & 50 \\
Ireland & 29,3 & 26,1 & 95 & 95 \\
Netherlands & 51,3 & 45,9 & 145 & 144 \\
Portugal & 34,4 & 35,2 & 22 & 43 \\
Spain & 33,5 & 31,7 & 54 & 40 \\
Sweden & 29,4 & 27,3 & 66 & 73 \\
United Kingdom & 17,5 & 18,1 & 86 & 97 \\
Unweighted average & & & & \\
Overall & 24,3 & 22,0 & 87,5 & 93,5 \\
Group A & 30,6 & 31,6 & 52,5 & 52,5 \\
Group B & 40,6 & 42,2 & 98,0 & 100,7 \\
Group C & 23,4 & 22,1 & 90,5 & 96,0 \\
European Union & 34,0 & 34,7 & 80,4 & 83,0 \\
Unweighted standard deviation & & & & \\
Overall & 10,67 & 13,67 & 29,87 & 28,18 \\
Group A & 9,10 & 6,78 & 24,12 & 16,86 \\
Group B & 9,97 & 16,27 & 26,61 & 23,00 \\
Group C & 23,40 & 22,10 & 90,50 & 96,00 \\
European Union & 10,67 & 13,67 & 29,87 & 28,18 \\
between groups (A.B.C) & 8,62 & 10.05 & 24.39 & 26.56 \\
\hline
\end{tabular}

Group A (Southern Europe): France, Italy, Portugal, Spain

Group B (Continental Europe): Austria, Denmark, Finland, Germany, Belgium, Netherlands Group C (Common-law countries): United Kingdom, Ireland 
Table 11

Convergence in Bargaining Institutions

\begin{tabular}{|c|c|c|c|c|c|c|c|c|c|c|c|c|}
\hline \multirow[b]{2}{*}{ Country } & \multicolumn{3}{|c|}{ Coverage } & \multicolumn{3}{|c|}{ Unionisation } & \multicolumn{3}{|c|}{ Centralisation } & \multicolumn{3}{|c|}{ Co-ordination } \\
\hline & 1980 & 1985 & 1995 & 1980 & 1985 & 1995 & 1980 & 1985 & 1995 & 1980 & 1985 & 1995 \\
\hline Australia & 88 & 80 & 80 & 48 & 41 & 35 & 2,2 & 1,5 & 1,5 & 2,2 & 2,2 & 1,5 \\
\hline Austria & 98 & 98 & 98 & 56 & 46 & 42 & 2,2 & 2,2 & 2,2 & 3,0 & 3,0 & 3,0 \\
\hline Belgium & 90 & 90 & 90 & 56 & 51 & 53 & 2,2 & 2,2 & 2,2 & 2,0 & 2,0 & 2,0 \\
\hline Canada & 37 & 38 & 36 & 35 & 34 & 33 & 1,0 & 1,0 & 1,0 & 1,0 & 1,0 & 1,0 \\
\hline Denmark & 69 & 69 & 69 & 76 & 71 & 76 & 2,2 & 2,0 & 2,0 & 2,5 & 2,2 & 2,2 \\
\hline Finland & 95 & 95 & 95 & 70 & 72 & 81 & 2,5 & 2,2 & 2,2 & 2,2 & 2,2 & 2,2 \\
\hline France & 85 & 92 & 95 & 17 & 10 & 9 & 2,0 & 2,0 & 2,0 & 1,8 & 2,0 & 2,0 \\
\hline Germany & 91 & 90 & 92 & 36 & 33 & 29 & 2,0 & 2,0 & 2,0 & 3,0 & 3,0 & 3,0 \\
\hline Italy & 85 & 83 & 82 & 57 & 50 & 50 & 1,0 & 1,0 & 1,0 & 1,0 & 1,0 & 1,0 \\
\hline Japan & 28 & 23 & 21 & 31 & 25 & 24 & 1,8 & 1,8 & 2,0 & 1,5 & 1,5 & 2,5 \\
\hline Netherlands & 76 & 71 & 81 & 31 & 25 & 24 & 1,0 & 1,0 & 1,0 & 3,0 & 3,0 & 3,0 \\
\hline New Zeland & 67 & 67 & 31 & 31 & 25 & 26 & 2,0 & 2,0 & 2,0 & 2,0 & 2,0 & 2,0 \\
\hline Norway & 75 & 75 & 74 & 56 & 45 & 24 & 2,0 & 1,5 & 1,1 & 1,5 & 1,0 & 1,0 \\
\hline Portugal & 70 & 79 & 71 & 57 & 56 & 58 & 2,0 & 2,2 & 2,2 & 2,5 & 2,5 & 2,5 \\
\hline Spain & 76 & 76 & 78 & 61 & 30 & 25 & 1,8 & 2,2 & 2,0 & 1,8 & 2,0 & 2,0 \\
\hline Sweden & 86 & 86 & 89 & 13 & 16 & 21 & 2,2 & 2,0 & 2,0 & 2,0 & 2,0 & 2,0 \\
\hline United Kingdom & 70 & 47 & 47 & 80 & 83 & 91 & 3,0 & 2,2 & 2,0 & 2,5 & 2,2 & 2,0 \\
\hline $\begin{array}{l}\text { United States } \\
\text { Unweighted averages }\end{array}$ & 26 & 18 & 18 & 50 & 39 & 34 & 2,0 & 1,8 & 1,6 & 1,5 & 1,2 & 1,0 \\
\hline Overall & 73 & 71 & 69 & 48 & 42 & 41 & 2 & 2 & 2 & 2 & 2 & 2 \\
\hline Group A & 79 & 83 & 82 & 48 & 36 & 35 & 2 & 2 & 2 & 2 & 2 & 2 \\
\hline Group B & 85 & 84 & 85 & 54 & 48 & 46 & 2 & 2 & 2 & 2 & 2 & 2 \\
\hline Group C & 50 & 43 & 33 & 49 & 45 & 46 & 2 & 2 & 2 & 2 & 2 & 2 \\
\hline European Union & 83 & 81 & 82 & 51 & 45 & 47 & 2 & 2 & 2 & 2 & 2 & 2 \\
\hline Unweighted standard dev & & & & & & & & & & & & \\
\hline Overall & 21,7 & 24,0 & 26,6 & 19,1 & 19,8 & 22,8 & 0,5 & 0,4 & 0,5 & 0,6 & 0,7 & 0,7 \\
\hline Group A & 7,3 & 7,0 & 10,1 & 20,5 & 21,0 & 22,5 & 0,5 & 0,6 & 0,5 & 0,6 & 0,6 & 0,6 \\
\hline Group B & 10,5 & 11,2 & 10,4 & 15,3 & 16,6 & 22,5 & 0,4 & 0,4 & 0,5 & 0,6 & 0,7 & 0,7 \\
\hline Group C & 21,9 & 20,3 & 12,0 & 22,2 & 25,7 & 30,1 & 0,8 & 0,5 & 0,5 & 0,6 & 0,6 & 0,6 \\
\hline European Union & 9,7 & 13,3 & 13,7 & 20,2 & 21,3 & 25,4 & 0,5 & 0,4 & 0,5 & 0,6 & 0,7 & 0,7 \\
\hline between groups (A.B.C) & 18.8 & 23.4 & 29.0 & 3.0 & 6.1 & 6.0 & 0.2 & 0.1 & 0.1 & 0.4 & 0.4 & 0.4 \\
\hline
\end{tabular}

Group A (Southern Europe): France, Italy, Portugal, Spain

Group B (Continental Europe): Australia, Austria, Denmark, Finland, Germany, Belgium, Netherlands, Norway, Switzerland

Group C (Common-law countries): United States, United Kingdom, Canada, Ireland, New Zeland

\section{Tentative conclusions}

This paper uses a novel set of indicators of regulation in the product and labour markets to shed some light on cross-country differences in the level and composition of employment and to discuss the likely effects of regulatory reforms on the OECD labour markets. In addition, comparing differences in regulatory policies with the changing patterns of social policies has allowed a preliminary investigation of the possible linkages between regulatory environments, different degrees of economic integration and the characteristics of the welfare systems in European countries.

Indicators of employment protection legislation (EPL) and of various dimensions of product market regulation suggest that, despite the widespread regulatory reforms, OECD countries remain characterised by widely different approaches to regulating product and labour markets. Overall, countries tend to adopt similar approaches in the two markets: where product markets are adverse to competition and state interference in the business sector is high, labour markets tend as well to have tight legislations protecting the employed pool. Therefore, clear country clusters can be identified according to the degree of strictness of regulations in the two markets:

Even controlling for a number of policy and institutional factors affecting the labour market, it is possible to detect significant effects of the summary indicators of both EPL and product market regulation 
on the level and the composition of employment rates of OECD countries. In particular, countries with tight EPL and restrictive product market regulation tend to have lower employment rates in the nonagricultural business sector. At the same time, biases in the regulatory environment will tend to distort the composition of employment. For instance, a more restrictive EPL for regular workers relative to temporary employment tends to increase the proportion of workers moving from one temporary contract to another. Similarly, higher regulatory and administrative burdens for corporations relative to sole proprietor companies tend to increase the proportion of self-employed in the non-agricultural business sector.

A widespread (but often slow-moving) tendency to reform product market regulation can be observed in European countries, mainly as a result of EC initiatives. By contrast, policies, institutions and regulations affecting the labour market move in largely idiosyncratic ways, with most countries implementing largely marginal reforms. In this context, one could ask whether OECD institutions are acquiring those features that are most conducive to foster employment rates. Our analysis suggests that the answer should be a timid yes. Institutions are changing and much more than usually thought, and generally in a direction that one can consider rather desirable in the light of our econometric results. Yet, much ground remains to be covered, most reforms are marginal and piecemeal in scope, and there is nothing irreversible in them. The expectation of reversals in reform strategies may seriously jeopardise reform efforts because regulatory changes lacking credibility may be ineffective. Contrary to claims commonly made that stricter economic integration should foster competition across national systems -- and hence stimulate institutional reforms converging to the best practices -- stronger integration in the EU area does not seem to have been associated so far with convergence in a number of labour market institutional features, such as employment protection, collective bargaining, as well as the size and structure of social expenditure. The degree in which EMU will feed in this process is highly uncertain and theorists are divided in assessing the role that the monetary union will play in the deepening and furthering of structural reforms. While a careful wait and see behaviour should be recommended to those researchers who do not want to enter a too speculative debate, those involved in policy-making should be aware of the fact that economic convergence does not necessarily exert competitive pressures on national institutions imposing increased efficiency in social welfare and employment protection provisions. Hence, if they deem that social welfare reforms are necessary, they should not spare energies in trying to support them. 


\section{BIBLIOGRAPHY}

AKERLOF, G. (1984), An Economist's Book of Tales, Cambridge University Press, Cambridge.

BENTOLILA, S. and BERTOLA, G. (1990), "Firing Costs and Labour Demand: How Bad is Eurosclerosis?", Review of Economic Studies, No. 57, pp. 381-402.

BENTOLILA, S. and J.J. DOLADO (1994), "Labour flexibility and wages: Lessons from Spain", Economic Policy, No. 18, April.

BERGEIJK, P.A.G. VAN and R.C.G. HAFFNER (1996), Privatisation, Deregulation and the Macroeconomy, Cheltenham, UK, Edward Elgar

BERLAGE, L. and D. TERWEDUWE (1988), "The Classification of Countries by Cluster and Factor Analysis", World Development, Vol. 16, No. 12, pp. 1527-1545.

BERTOLA, G. (1990), "Job Security, Employment and Wages", European Economic Review, Vol. 34, North Holland, pp. 851-886.

BERTOLA, G. (1999), "Microeconomic Perspectives on Aggregated Labour Markets", mimeo. Forthcoming in the Handbook of Labor Economics, Vol. 3.

BERTOLA, G. and ROGERSON, R. (1997), "Institutions and Labor Reallocation", European Economic Review, Vol. 41, pp. 1147-1171.

BERTOLA, G. (1992), "Labour turnover costs and average labour demand", Journal of Labour Economics, No. 4.

BLANCHARD, O. (1998), “Thinking about Unemployment”, mimeo.

BLANCHARD, O. and PORTUGAL, P. (1998), "What Hides Behind an Unemployment Rate: Comparing Portuguese and US Unemployment", National Bureau of Economic Research, Working Paper No. 6636.

BOERI, T. (1999), "Enforcement of Employment Security Regulations, On-the-job Search and Unemployment Duration", European Economic Review, Vol. 43, pp. 65-89.

BUREAU OF INDUSTRY ECONOMICS (1996) Business Licenses. International Benchmarking Report 96/9, Canberra.

BUTI, M., L.R. PENCH and P. SESTITO (1998), "European unemployment: contending theories and institutional complexities", Economic and Financial Reports, BEI/EIB, Report 98/01.

CALMFORS, L. (1998) "Macroeconomic Policy, Wage Setting and Employment: What Difference Does the EMU Make?", Institute for International Economic Studies, Seminar Paper n.657. 
Centre Européen des Entreprises à Participation Publique, CEEP (1997) Annales Statistiques.

ELMESKOV, J., MARTIN, J.P. and SCARPETTA, S. (1998), "Key Lessons for Labour Market Reforms: Evidence from OECD Countries' Experience", Swedish Economic Policy Review, Vol. 5, no. 2, 1998.

GRUBB, D. and WELLS, W. (1993), "Employment Regulation and Patterns of Work in EC Countries", OECD Economic Studies, No. 21, Winter, pp. 7-58.

GWARTNEY, J. and R. LAWSON (1997), Economic Freedom of the World 1997, Annual Report, the Fraser Institute, Vancouver, B.C.

JACKMAN, R., LAYARD, R. and NICKELL, S. (1996), "Combating Unemployment: Is Flexibility Enough”, Centre for Economic Performance Discussion Paper No. 293.

KOEDJIK, K. and J. KREMERS (1996), "Market opening, regulation and growth in Europe”, Economic Policy, Vol.

KRUEGER, A. and PISCHKE, J.-S. (1997), "Observations and Conjectures on the U.S. Employment Miracle", Working Paper Department of Economics, No. 97-16, August, Massachusetts Institute of Technology.

LAZEAR, E.P. (1990), "Job Security Provisions and Employment", The Quarterly Journal of Economics, August, pp. 699-726.

LINDBECK, A., and SNOWER, D.J. (1988), The Insider-Outsider Theory of Employment and Unemployment, MIT Press, Cambridge, Massachusetts.

NICKELL, S. (1997), "Unemployment and Labor Market Rigidities: Europe versus North America", Journal of Economic Perspectives, Vol. 11, No. 3, Summer, pp. 55-74.

NICKELL, S. and LAYARD, R. (1998), "Labour Market Institutions and Economic Performance", Centre for Economic Performance, Discussion Paper No. 407, September. Forthcoming in the Handbook of Labor Economics, Vol. 3.

NICOLETTI, G. and S. SCARPETTA (1999), "Product and labour market regulations and performance in the OECD labour markets", OECD, Economics Department Working Paper, forthcoming.

NICOLETTI, G., S. SCARPETTA and O. BOYLAUD (1999), "Summary indicators of employment protection legislation and product market regulations for the purpose of international comparisons", mimeo.

NOLL, R. (1989a), "Economic Perspectives on the Politics of Regulation" in Handbook of Industrial Organization, Vol.2, eds. R. Schmalensee and R.D. Willig, Amsterdam: North-Holland, pp. 1253-87

NOLL, R. (1989b), "The Economic Theory of Regulation after a Decade of Deregulation: Comments", Brookings Papers on Economic Activity: Microeconomics, pp. 48-58.

OECD (1994a), “The OECD Jobs Study: Facts, Analysis, and Strategies”, Paris.

OECD (1994b), “The OECD Jobs Study, Evidence and Explorations, Part II”, Paris. 
OECD (1997a) Indicators of Tariff and Non-tariff Trade Barriers, Paris.

OECD (1997b), The OECD Report on Regulatory Reform, Paris.

OECD (1999a), “Employment Outlook”, Paris.

OECD (1999b), “Implementing the OECD Jobs Strategy: Assessing Performance and Policy”, Paris.

OFFICE OF MANAGEMENT AND BUDGET, (1998), US Office of Information and Regulatory Affairs, Draft Report to Congress on the Cost and Benefits of Federal Regulations

PELTZMAN, S. (1989), “The Economic Theory of Regulation after a Decade of Deregulation”, Brookings Papers on Economic Activity: Microeconomics, pp. 1-41

PHELPS, E. S. (1994), "Structural Slumps: The Modern Equilibrium Theory of Unemployment, Interest and Assets", Cambridge, Mass: Harvard University Press.

PIORE, M. (1986), “Labor Market Flexibility”, University of California, Berkeley, CA.

SAINT PAUL, G. (1996), “Dual Labour Markets”, The MIT Press, Cambridge Massachusetts.

SCARPETTA, S. (1996), "Assessing the Role of Labour Market Policies and Institutional Settings on Unemployment: A Cross-Country Study”, OECD Economic Studies, No. 26, 1996/1.

SINN, H. (1998), "European Integration and the Future of the Welfare State", CEPR Discussion Papers, n. 1871.

VICKERS, J. and G. YARROW (1991), "Economic Perspectives on Privatization", Journal of Economic Perspectives, Vol. 5, No. 2, pp. 111-132.

VISCUSI, W. K., J. M. VERNON and J. E. HARRINGTON, JR., (1997), Economics of Regulation and Antitrust, The MIT Press, Cambridge, Massachusetts, pp. 307-311.

WINSTON, C. (1993), "Economic Deregulation: Days of Reckoning for Microeconomists", Journal of Economic Literature, Vol. XXXI, No. 3, pp. 1263-89.

WINSTON, C. and R.W. CRANDALL (1994), "Explaining Regulatory Policy", Brookings Papers on Economic Activity: Microeconomics, Brookings Institution, Washington D.C., pp. 1-49.

WORLD BANK (1995), Bureaucrats in Business: The Economics and Politics of Government Ownership, World Bank Policy Research Reports, World Bank, Washington D.C. 